\title{
Persistent influence of ice sheet melting on high northern latitude climate during the early Last Interglacial
}

\author{
A. Govin ${ }^{1, *}$, P. Braconnot ${ }^{1}$, E. Capron ${ }^{1, * *}$, E. Cortijo ${ }^{1}$, J.-C. Duplessy ${ }^{1}$, E. Jansen ${ }^{2}$, L. Labeyrie ${ }^{1}$, A. Landais ${ }^{1}$, \\ O. Marti ${ }^{1}$, E. Michel ${ }^{1}$, E. Mosquet ${ }^{1}$, B. Risebrobakken ${ }^{2}$, D. Swingedouw ${ }^{1}$, and C. Waelbroeck ${ }^{1}$ \\ ${ }^{1}$ LSCE/IPSL Laboratoire des Sciences du Climat et de l'Environnement, CEA-CNRS-UVSQ - UMR8212, \\ Gif sur Yvette, France \\ ${ }^{2}$ Bjerknes Centre for Climate Research, University of Bergen, Bergen, Norway \\ *now at: MARUM/Center for Marine Environmental Sciences, University of Bremen, Leobener Strasse, Bremen, Germany \\ ** now at: British Antarctic Survey, High Cross, Madingley Road, Cambridge, CB3 0ET, UK
}

Correspondence to: A. Govin (aline.govin@uni-bremen.de)

Received: 3 October 2011 - Published in Clim. Past Discuss.: 11 October 2011

Revised: 6 February 2012 - Accepted: 7 February 2012 - Published: 14 March 2012

\begin{abstract}
Although the Last Interglacial (LIG) is often considered as a possible analogue for future climate in high latitudes, its precise climate evolution and associated causes remain uncertain. Here we compile high-resolution marine sediment records from the North Atlantic, Labrador Sea, Norwegian Sea and the Southern Ocean. We document a delay in the establishment of peak interglacial conditions in the North Atlantic, Labrador and Norwegian Seas as compared to the Southern Ocean. In particular, we observe a persistent iceberg melting at high northern latitudes at the beginning of the LIG. It is associated with (1) colder and fresher surfacewater conditions in the North Atlantic, Labrador and Norwegian Seas, and (2) a weaker ventilation of North Atlantic deep waters during the early LIG (129-125 ka) compared to the late LIG. Results from an ocean-atmosphere coupled model with insolation as a sole forcing for three key periods of the LIG show warmer North Atlantic surface waters and stronger Atlantic overturning during the early LIG (126 ka) than the late LIG (122 ka). Hence, insolation variations alone do not explain the delay in peak interglacial conditions observed at high northern latitudes. Additionally, we consider an idealized meltwater scenario at $126 \mathrm{ka}$ where the freshwater input is interactively computed in response to the high boreal summer insolation. The model simulates colder, fresher North Atlantic surface waters and weaker Atlantic overturning during the early LIG (126 ka) compared to the late LIG $(122 \mathrm{ka})$. This result suggests that both insolation and ice sheet melting have to be considered to reproduce the climatic
\end{abstract}

pattern that we identify during the early LIG. Our modeldata comparison also reveals a number of limitations and reinforces the need for further detailed investigations using coupled climate-ice sheet models and transient simulations.

\section{Introduction}

The Last Interglacial (LIG) period (129-118 ka, $1 \mathrm{ka}=1000$ years) is also termed Marine Isotope Stage 5.5 (MIS 5.5) in marine sediment cores or Eemian in European continental records (e.g. Kukla et al., 1997, 2002). This period is characterized by a high-latitude climate warmer by several degrees than today (North Greenland Ice Core Project members, 2004; Cape Last Interglacial Project members, 2006; EPICA Community members, 2006; Clark and Huybers, 2009). Sea level was at least $6 \mathrm{~m}$ above the present level (Kopp et al., 2009) due to smaller glacier ice volume (e.g. Koerner, 1989; Otto-Bliesner et al., 2006) in response to the high boreal summer insolation (e.g. Berger and Loutre, 1991). Given its high insolation forcing, the LIG is generally regarded as a potential analogue for future climate evolution (e.g. Kukla et al., 2002; Jansen et al., 2007).

Characterized by extreme seasonal variations in temperature-sensitive processes (e.g. sea ice extent) and large-scale feedbacks mechanisms, polar regions are particularly sensitive to variations in climate forcing and are expected to experience large environmental changes in the 
near future (Meehl et al., 2007). The sequence of variations in the surface and deep oceans is well documented at high northern and southern latitudes during the last deglaciation (Termination I, see Denton et al., 2010 for a review). Most marine records from the North Atlantic and the Nordic Seas indicate an early to mid-Holocene $(\sim 10-8 \mathrm{ka})$ oceanic thermal optimum (e.g. Birks and Koç, 2002; Calvo et al., 2002; Hald et al., 2007; Bauch and Erlenkeuser, 2008; Andersson et al., 2010; Risebrobakken et al., 2011), in agreement with maximum boreal summer insolation values recorded at $11 \mathrm{ka}$ (e.g. Berger and Loutre, 1991). Similarly, high southern latitudes exhibit high temperatures as early as $11.7 \mathrm{ka}$ in the Southern Ocean (e.g. Calvo et al., 2007; Skinner et al., 2010) and over Antarctica (e.g. EPICA Community members, 2006; Stenni et al., 2011). In contrast, sea level rose ca. $60 \mathrm{~m}$ during the early Holocene until $7 \mathrm{ka}$ when the Holocene sea level highstand was reached (e.g. Smith et al., 2011 for a review).

The deglacial history of the penultimate deglaciation (Termination II) is less documented. For example, discrepancies exist between marine records on the existence of a northern temperature reversal during Termination II (Sarnthein and Tiedemann, 1990; Adkins et al., 1997; Chapman and Shackleton, 1998; Oppo et al., 2001; Kelly et al., 2006; Desprat et al., 2007; Weldeab et al., 2007). The establishment of the peak interglacial warmth at high northern latitudes during the LIG also remains controversial. Some studies showed evidence for an early LIG development of peak interglacial conditions in the Norwegian Sea and a later climatic optimum at mid latitudes in the North Atlantic (Cortijo et al., 1994, 1999). In contrast, other studies highlighted an early warming phase in the North Atlantic during the LIG (Rasmussen et al., 2003b; Bauch and Kandiano, 2007) and a late warming phase in the Norwegian Sea (Fronval and Jansen, 1997; Fronval et al., 1998; Rasmussen et al., 2003b). Part of these discrepancies arise from the difficulty of (1) collecting marine sediment cores from the Nordic Seas with high sedimentation rates during the LIG, and (2) defining reliable stratigraphical time frames between the North Atlantic and the Nordic Seas during the LIG (e.g. Fronval and Jansen, 1997; Cortijo et al., 1999; Rasmussen et al., 2003b; Risebrobakken et al., 2005, 2006; Bauch and Erlenkeuser, 2008).

Recent high-resolution Norwegian Sea records suggest that the LIG thermal optimum in the Norwegian Sea occurred relatively late after the penultimate deglaciation (Bauch and Erlenkeuser, 2008; Bauch et al., 2011; Van Nieuwenhove et al., 2011), at a time when the boreal summer insolation was already significantly reduced (e.g. Berger and Loutre, 1991). They also show that the LIG peak warmth in the Norwegian Sea never reached the high warmth level of the early Holocene (Bauch and Erlenkeuser, 2008; Bauch et al., 2011), although the boreal summer insolation at the beginning of the LIG was higher by $20 \mathrm{~W} \mathrm{~m}^{-2}$ than during the early Holocene. This weakened LIG warmth in comparison to the early Holocene suggests that the temperature evolu- tion in the Nordic Seas does not solely respond to insolation variations during the LIG (Bauch et al., 2011).

The Late Saalian glacial period (160-140 ka) preceding the LIG was a prolonged cold period in Europe characterized by a large Eurasian ice sheet that extended from the Norwegian shelf to the Barents-Kara Sea further south than any subsequent glacial episode (e.g. Svendsen et al., 2004). The Eurasian Saalian ice sheet retreated relatively quickly during Termination II. For example, grounded ice remained only on northern Scandinavia, the present Kara Sea and Arctic islands at ca. $134 \mathrm{ka}$ (Lambeck et al., 2006). High boreal summer insolation explains the rapidity of northern ice sheet retreat during the penultimate deglaciation (Ruddiman et al., 1980). This fast ice sheet melting, which induced high meltwater discharge (Carlson, 2008) and reduced Atlantic Meridional Overturning Circulation (AMOC) throughout the deglaciation (Oppo et al., 1997), also likely explains the absence of a Younger Dryas-like event during Termination II (Ruddiman et al., 1980; Carlson, 2008). Uncertainties however remain on the timing of the LIG sea level highstand ranging from around $129 \mathrm{ka}$ to around $124 \mathrm{ka}$ (Cutler et al., 2003; Siddall et al., 2003; Thompson and Goldstein, 2006; Rohling et al., 2008; Waelbroeck et al., 2008; Blanchon et al., 2009). Hence, continued melting from the Eurasian Saalian ice sheet at the beginning of the LIG may have contributed to the delay in peak interglacial warmth recently documented in the Norwegian Sea (Bauch et al., 2011; Van Nieuwenhove et al., 2011).

The objectives of this study are twofold. First we investigate the geographical polar extension of the late thermal optimum recorded in Norwegian Sea surface waters during the LIG and its potential counterpart in deep waters. For that purpose, we compiled five high-resolution marine sediment records from the North Atlantic, Labrador Sea and Norwegian Sea that we compare with a sediment record from the Southern Ocean, taken as a reference for high southern latitude climate. We define a consistent time frame between the Norwegian Sea, Labrador Sea, the North Atlantic and Southern Ocean during the LIG and compare the timing of establishment of high-latitude peak interglacial conditions recorded by surface and deep waters. Second, we use a coupled ocean-atmosphere general circulation model to investigate the plausible causes (insolation changes versus meltwater input) responsible for the late oceanic climate optimum observed at high northern latitudes during the LIG. We discuss the results of the model simulations performed for three key periods of the LIG and the limits of the model-data intercomparison. 
Table 1. Cores considered in this study (the location of cores from the North Atlantic, Labrador and Norwegian Seas is shown in Fig. 9).

\begin{tabular}{llrrrl}
\hline Ocean & Core & Latitude & Longitude & Depth & Reference \\
\hline Norwegian Sea & MD95-2010 & $66.68^{\circ} \mathrm{N}$ & $4.57^{\circ} \mathrm{E}$ & $1226 \mathrm{~m}$ & Risebrobakken et al. (2005, 2006) \\
Labrador Sea & EW9302-JPC2 & $48.80^{\circ} \mathrm{N}$ & $45.09^{\circ} \mathrm{W}$ & $1251 \mathrm{~m}$ & Rasmussen et al. (2003b) \\
North Atlantic & ODP 980 & $55.49^{\circ} \mathrm{N}$ & $14.70^{\circ} \mathrm{W}$ & $2168 \mathrm{~m}$ & McManus et al. (1999); Oppo et al. (2006) \\
& CH69-K09 & $41.76^{\circ} \mathrm{N}$ & $47.35^{\circ} \mathrm{W}$ & $4100 \mathrm{~m}$ & Cortijo et al. (1999); Labeyrie et al. (1999) \\
& MD95-2042 & $37.80^{\circ} \mathrm{N}$ & $10.17^{\circ} \mathrm{W}$ & $3146 \mathrm{~m}$ & Shackleton et al. (2000, 2002) \\
Southern Ocean & MD02-2488 & $46.47^{\circ} \mathrm{S}$ & $88.02^{\circ} \mathrm{E}$ & $3420 \mathrm{~m}$ & Govin et al. (2009) \\
\hline
\end{tabular}

\section{Material and methods}

\subsection{Marine sediment cores and analyses}

\subsubsection{Sediment cores}

We selected six marine sediment cores with a relatively high sedimentation rate (ranging from $\sim 5$ to $17 \mathrm{~cm} \mathrm{ka}^{-1}$ ) during the LIG (see Table 1 for the name and references of the cores). We chose three cores in the North Atlantic located at increasing water-depths from $2000 \mathrm{~m}$ to $4000 \mathrm{~m}$ (Table 1). The core locations presently lie in North Atlantic Deep Waters (NADW). We completed this dataset with two sediment cores collected from basins of modern deep-water formation: one in the Norwegian Sea and one in the Labrador Sea (Table 1). Finally, we chose one sediment core from the Indian sector of the Southern Ocean as a reference for the LIG climate evolution in southern subpolar regions (Table 1). Complementary proxies (foraminiferal stable isotope analyses, sea surface temperature and ice-rafted detritus reconstructions) are available in these cores during our period of interest (132-115 ka).

\subsubsection{Stable isotopes}

All discussed cores present high-resolution oxygen and carbon isotopic $\left(\delta^{18} \mathrm{O}\right.$ and $\left.\delta^{13} \mathrm{C}\right)$ records obtained on both planktic and benthic foraminifera. Foraminiferal $\delta^{18} \mathrm{O}$ and $\delta^{13} \mathrm{C}$ analyses are expressed in \%o versus Vienna PDB, defined with respect to NBS 19 calcite standard $\left(\delta^{18} \mathrm{O}=-2.20 \%\right.$ and $\delta^{13} \mathrm{C}=+1.95 \%$ ) $)$. We present the benthic $\delta^{18} \mathrm{O}$ data on the Uvigerina scale and show $\delta^{13} \mathrm{C}$ data measured on the epibenthic Cibicides genus only. We increased the resolution of the benthic foraminiferal isotopic record from the Southern Ocean core reported by Govin et al. (2009) and generated a benthic record with a resolution better than $0.5 \mathrm{ka}$ over the entire period 130-115 ka.

\subsubsection{Sea surface temperatures}

Reconstructions of summer sea surface temperatures (SST) are exclusively based on faunal assemblages of foraminifera in the North Atlantic and Southern Ocean cores for higher consistency. We increased the resolution of SST data from the Southern Ocean core to an averaged resolution of $0.4 \mathrm{ka}$ during the LIG, following the methodology described in Govin et al. (2009). In the Norwegian and Labrador Sea cores, SST estimates are originally based on the percentage of the polar foraminifera species Neogloboquadrina pachyderma sinistral. In order to indicate the range of temperature change in the Norwegian and Labrador Seas, we converted the percentages of $N$. pachyderma sinistral into summer SST. The calibration is derived from the MARGO dataset comprising 862 sites in the North Atlantic and the Nordic Seas (Kucera et al., 2005). We calculated the linear relationship linking the percentage of $N$. pachyderma sinistral at high northern latitudes and the summer SST (averaged JulyAugust-September temperatures taken at $10 \mathrm{~m}$ water-depth from the World Ocean Atlas 2001; Stephens et al., 2002, following Kucera et al., 2005) (Fig. 1). Based on the sites characterized by summer SST below $15^{\circ} \mathrm{C}$ and percentages of $N$. pachyderma sinistral ranging from 10 to $94 \%$, we defined the regression in the 6 to $12^{\circ} \mathrm{C}$ range (Fig. 1). The root mean square deviation of the relationship is $\pm 1.8^{\circ} \mathrm{C}$ $(1 \sigma)$. Modifying the calibration interval (e.g. $10-94 \%$ or $13-84 \%$ ) produces similar linear relationships within uncertainties. The change in reconstructed SST ranges from $<0.1^{\circ} \mathrm{C}$ to $0.7^{\circ} \mathrm{C}$ for respectively high and low percentages of $N$. pachyderma. The effect of the calibration interval on reconstructed SST remains small. The calibration provides a reliable range of temperature change in the Norwegian and Labrador Seas. The uncertainty on $N$. pachyderma sinistral percentages $(<5 \%)$ results in small SST uncertainties (ranging from $0.3^{\circ} \mathrm{C}$ to $0.7^{\circ} \mathrm{C}$ for respectively low and high $N$. pachyderma percentages). The error on the calibration $\left(1.8^{\circ} \mathrm{C}\right)$ hence dominates the total error $\left(1.9^{\circ} \mathrm{C}\right)$ on SST reconstructed from $N$. pachyderma sinistral percentages.

\subsubsection{Ice rafted detritus}

IRD data are expressed as the number of lithic grains per gram of dry sediment. IRD $>150 \mu \mathrm{m}$ were counted in the North Atlantic cores, whereas IRD $>500 \mu \mathrm{m}$ were counted in the Norwegian Sea core. 


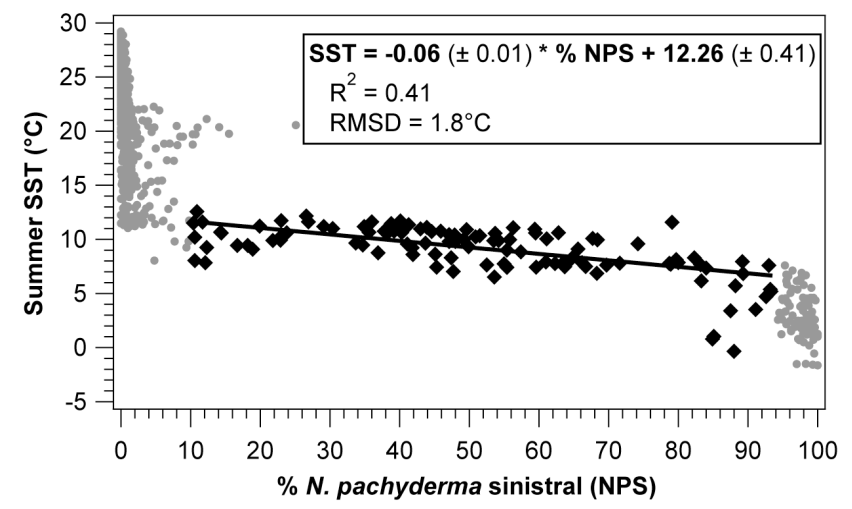

Fig. 1. Linear relationship defined between summer SST and the percentage of the polar planktic species Neogloboquadrina pachyderma sinistral (NPS) in the North Atlantic. We used the MARGO database from the North Atlantic (Kucera et al., 2005). The relationship (thick black line) is defined for summer SST below $15^{\circ} \mathrm{C}$ and percentages of $N$. pachyderma sinistral between $10 \%$ and $94 \%$ (black diamonds). The grey circles represent the other sites of the database characterized by SST values above $15^{\circ} \mathrm{C}$ or by percentages of $N$. pachyderma sinistral above $94 \%$ or below $10 \%$. The root mean square deviation (RMSD) of the relationship is $\pm 1.8^{\circ} \mathrm{C}$ $(1 \sigma)$.

\subsubsection{Seawater $\delta^{18} O$}

Finally, we reconstructed seawater $\delta^{18} \mathrm{O}\left(\delta^{18} \mathrm{O}_{\mathrm{sw}}\right)$ variations in the North Atlantic cores CH69-K09 and ODP 980. We calculated $\delta^{18} \mathrm{O}_{\mathrm{sw}}$ values as the residual (e.g. Duplessy et al., 1991) between the planktic $\delta^{18} \mathrm{O}$ records (from Globigerina bulloides in core CH69-K09 and N. pachyderma dextral in core ODP 980) and SST records using the following paleotemperature equation (Shackleton, 1974):

$$
\begin{aligned}
T_{\text {iso }} & =16.9-4.38 \cdot\left(\delta^{18} \mathrm{O}_{\mathrm{c}}+0.27-\delta^{18} \mathrm{O}_{\mathrm{sw}}\right) \\
& +0.10 \cdot\left(\delta^{18} \mathrm{O}_{\mathrm{c}}+0.27-\delta^{18} \mathrm{O}_{\mathrm{sw}}\right)^{2} .
\end{aligned}
$$

$T_{\text {iso }}$ is the isotopic or calcification temperature $\left({ }^{\circ} \mathrm{C}\right) ; \delta^{18} \mathrm{O}_{\mathrm{c}}$, the isotopic composition of the calcite $(\% \circ \mathrm{PDB}) ; \delta^{18} \mathrm{O}_{\mathrm{sw}}$, the isotopic composition of seawater (\%o SMOW). The factor " 0.27 " is added for calibration against international standards.

In order to determine how much the calcification temperature of G. bulloides and N. pachyderma dextral deviates from the summer SST (e.g. Duplessy et al., 1991), we compared in both cores the averaged coretop $(0-3.5 \mathrm{ka})$ summer SST and the modern isotopic temperature that we calculated from the in situ $\delta^{18} \mathrm{O}_{\mathrm{sw}}$ value and the averaged coretop (0-3.5 ka) planktic $\delta^{18} \mathrm{O}$ value (see Table 2 for details). This approach accounts for the different calcification depths of G. bulloides and N. pachyderma dextral (Table 2). The calcification temperatures of $G$. bulloides and $N$. pachyderma dextral are

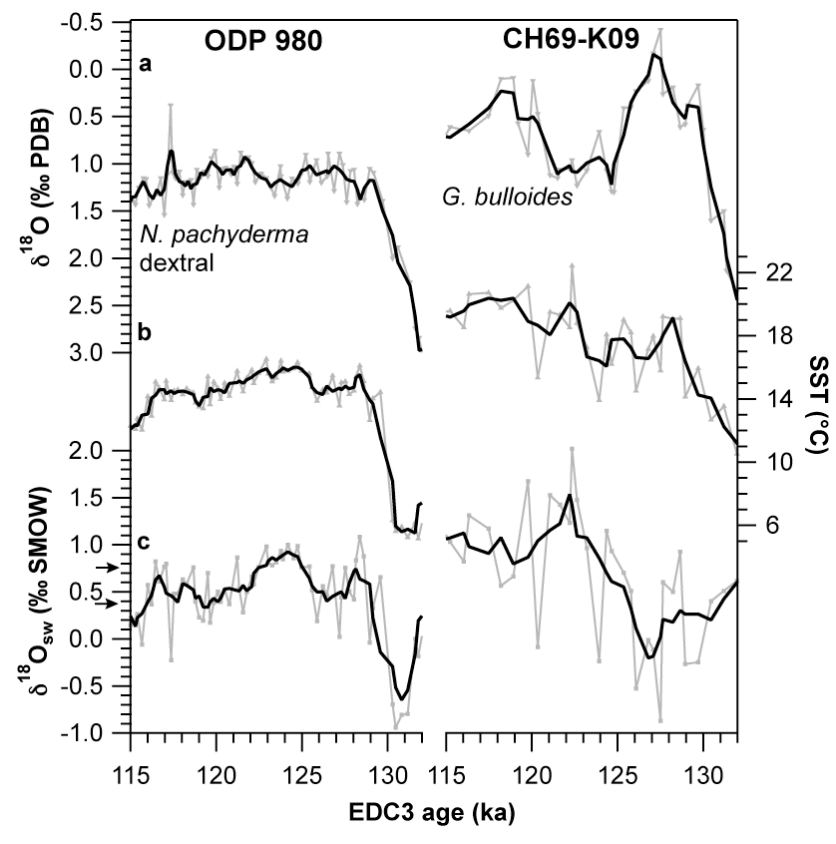

Fig. 2. Reconstruction of seawater $\delta^{18} \mathrm{O}\left(\delta^{18} \mathrm{O}_{\mathrm{sw}}\right)$ in cores ODP 980 (left panel) and CH69-K09 (right panel). For higher clarity, the records are shown versus age over the interval 115$132 \mathrm{ka}$ (see Sect. 3.1.1 and Fig. 5 for the definition of age models). (a) Planktic $\delta^{18} \mathrm{O}$ records from $N$. pachyderma dextral in core ODP 980 (Oppo et al., 2006) and G. bulloides in core CH69-K09 (Labeyrie et al., 1999). (b) Summer SST records (Labeyrie et al., 1999; Oppo et al., 2006). (c) Reconstructed seawater $\delta^{18}$ O. The arrows along the Y-axis highlight the modern $\delta^{18} \mathrm{O}_{\text {sw }}$ value at the site of core ODP $980(0.38 \%$ ) and CH69-K09 (0.75\%o) (Schmidt et al., 1999) (see Table 2). Grey lines show the raw data. Thick black lines are 3-point smoothing average for the planktic $\delta^{18} \mathrm{O}$ and SST records, and 5-point smoothing average for the $\delta^{18} \mathrm{O}_{\mathrm{sw}}$ records.

hence lower by respectively $2{ }^{\circ} \mathrm{C}$ and $1.5^{\circ} \mathrm{C}$ than the summer SST (Table 2). This deviation is identical to the most recent calibration for G. bulloides (Chapman et al., 2000). No such study exists so far for $N$. pachyderma dextral. Using these factors, we corrected the summer SST records from cores CH69-K09 and ODP 980 to reconstruct past $\delta^{18} \mathrm{O}_{\mathrm{sw}}$ variations (Fig. 2). Given the uncertainties on the timing of the LIG sea level highstand and the relatively small amplitude of sea level variations $(<10 \mathrm{~m})$ over the interval 130 $115 \mathrm{ka}$ (e.g. Waelbroeck et al., 2002; Thompson and Goldstein, 2006; Rohling et al., 2008; Blanchon et al., 2009), we did not correct here the $\delta^{18} \mathrm{O}_{\mathrm{sw}}$ values for ice volume variations. The uncertainty on $\delta^{18} \mathrm{O}_{\mathrm{sw}}$ estimates is around $\pm 0.5 \%$ o (e.g. Duplessy et al., 1991; Chapman et al., 2000; Malaizé and Caley, 2009). The SST and $\delta^{18} \mathrm{O}_{\mathrm{sw}}$ records from core $\mathrm{CH} 69-\mathrm{K} 09$, which is located at the boundary between the North Atlantic and Labrador currents (Labeyrie et al., 1999), show higher variability (Fig. 2) than core ODP 980 located along the pathway of the North Atlantic current (Oppo et al., 2006). 
Table 2. Geochemical and hydrological parameters used to calculate the isotopic temperature $\left(T_{\mathrm{iso}}\right)$ and the correction applied on SST from cores $\mathrm{CH} 69-\mathrm{K} 09$ and ODP 980 in order to reconstruct seawater $\delta^{18} \mathrm{O}\left(\delta^{18} \mathrm{O}_{\text {sw }}\right)$.

\begin{tabular}{|c|c|c|c|c|c|c|c|}
\hline Core & $\begin{array}{l}\text { Planktic } \\
\text { foraminifera } \\
\text { species }\end{array}$ & $\begin{array}{l}\text { Habitat } \\
\text { depth } \\
(\mathrm{m})\end{array}$ & $\begin{array}{c}\text { Coretop } \\
(0-3.5 \mathrm{ka}) \\
\delta^{18} \mathrm{O}_{\mathrm{c}} \\
(\% \circ \mathrm{PDB})\end{array}$ & $\begin{array}{c}\text { In situ } \\
\delta^{18} \mathrm{O}_{\mathrm{sw}} \\
(\% \text { SMOW })^{\mathrm{a}}\end{array}$ & $\begin{array}{l}T_{\text {iso }} \\
\left({ }^{\circ} \mathrm{C}\right)^{b}\end{array}$ & $\begin{array}{l}\text { Coretop } \\
(0-3.5 \mathrm{ka}) \\
\mathrm{SST} \\
\left({ }^{\circ} \mathrm{C}\right)\end{array}$ & $\begin{array}{l}\text { SST correction } \\
\left({ }^{\circ} \mathrm{C}\right)\end{array}$ \\
\hline CH69-K09 & G. bulloides & $0-60^{c}$ & 1.06 & $0.75^{\mathrm{e}}$ & 14.4 & 16.4 & $T_{\text {iso }}=\mathrm{SST}-2.0$ \\
\hline ODP 980 & N. pachyderma dextral & $30-100^{\mathrm{d}}$ & 1.24 & $0.38^{\mathrm{f}}$ & 12.1 & $13.6^{\mathrm{g}}$ & $T_{\text {iso }}=\mathrm{SST}-1.5$ \\
\hline
\end{tabular}

${ }^{a}$ Closest value to the core site extracted from the GISS database (Schmidt et al., 1999).

${ }^{\mathrm{b}}$ The isotopic temperature $\left(T_{\mathrm{iso}}\right)$ is derived from the coretop $(0-3.5 \mathrm{ka}) \delta^{18} \mathrm{O}_{\mathrm{c}}$ and in situ $\delta^{18} \mathrm{O}_{\mathrm{sw}}$ using the paleotemperature equation (Shackleton, 1974) reported in Sect. 2.1.5.

c Schiebel et al. (1997); Ganssen and Kroon (2000)

dOttens (1992); Came et al. (2007)

${ }^{\mathrm{e}}$ Data from the North Atlantic at $44.96^{\circ} \mathrm{N}, 42.08^{\circ} \mathrm{W}, 4 \mathrm{~m}$ water-depth (Ostlund et al., 1987). Although slightly too shallow, this station is the closest to the North Atlantic CH69-K09 with available data within the habitat range of $G$. bulloides.

${ }^{\mathrm{f}}$ Data from the North Atlantic at $55.3^{\circ} \mathrm{N}, 15.6^{\circ} \mathrm{W}, 46 \mathrm{~m}$ water-depth (Ostlund and Grall, 1993). Although slightly too shallow, this station is the closest to the North Atlantic ODP 980 with available data within the habitat range of $N$. pachyderma dextral.

${ }^{g}$ Coretop (0-3.5 ka) SST is that of core NA87-22 (Waelbroeck et al., 2001) from exactly the same location. SSTs have been reconstructed in the same way in cores ODP 980 and NA87-22 and show very high consistency (Masson-Delmotte et al., 2010).

\subsection{Model simulations}

To gain insight on the climate forcing and processes responsible for the late LIG oceanic optimum observed at high northern latitudes, we use model simulations performed with the coupled ocean-atmosphere general circulation model (GCM) IPSL-CM4 (Marti et al., 2010). It couples the atmospheric general circulation model LMDZ (Hourdin et al., 2006) to the OPA ocean circulation model (Madec et al., 1998). A dynamic-thermodynamic sea ice model (Fichefet and Maqueda, 1997) is coupled with the ocean-atmosphere model. The atmospheric model is coupled to the land scheme surface ORCHIDEE (Krinner et al., 2005). Details on the model components and the methodology of coupling are given by Marti et al. (2010). The model is run with a medium resolution. The atmospheric grid is regular, with 96 points in longitude $\left(3.75^{\circ}\right), 71$ points in latitude $\left(2.5^{\circ}\right)$ and 19 vertical levels. The oceanic resolution is about $2^{\circ}\left(0.5^{\circ}\right.$ near the equator) with 182 points in longitude, 149 points in latitude and 31 vertical levels.

We consider as a reference a 1000-year long simulation of the preindustrial climate. The performance of the IPSLCM4 model under preindustrial conditions is discussed by Swingedouw et al. (2007a) and Marti et al. (2010). In summary, the model exhibits a cold bias in the North Atlantic in comparison to modern observations. This bias is partly attributed to a weak Atlantic meridional overturning characterized by a maximum overturning of around $10.5 \mathrm{~Sv}$. Recent observation-based estimates are around $18.7 \pm 2.1 \mathrm{~Sv}$ (Kanzow et al., 2010). The mismatch between the observations and the simulation is larger than the difference between preindustrial and modern climates. The weak AMOC in the model mainly results from the absence of convection in the
Labrador Sea due to fresher than observed surface waters in this region. Excessive precipitation in the North Atlantic and a weak northward wind-driven salinity transport to the North Atlantic (resulting from an equatorward position of the zonal wind stress in comparison to observations) both contribute to the low salinity bias. A larger than observed export of sea ice across the Fram Strait finally reinforces the bias.

We consider the model outputs of a series of simulations performed for three time slices of the LIG (see Table 3 for a summary). Model simulations were forced with insolation values from Berger (1978) (Table 3) and the modern ice sheet configuration (Braconnot et al., 2008). The Greenland ice sheet (GIS) is hence the only northern ice sheet represented in the model. Greenhouse gas concentrations were prescribed to preindustrial values (Table 3) (Braconnot et al., 2008; Swingedouw et al., 2009).

We investigate the LIG response of high northern latitude climate to two different types of perturbation: (1) response to insolation variations only and (2) additional impact of a northern meltwater input. First, to study the effect of insolation variations on high northern latitude climate during the LIG, we use the results of simulations performed for three key periods of the LIG characterized by distinct insolation values (Braconnot et al., 2008): maximum in boreal summer insolation in the early LIG at $126 \mathrm{ka}$ (250 year-long simulation), intermediate insolation values in the mid LIG at $122 \mathrm{ka}$ (800 year-long simulation), and minimum in boreal summer insolation at $115 \mathrm{ka}$ (700 year-long simulation) (Table 3). The shortest simulation at $126 \mathrm{ka}$ (250 years) exhibits a stable AMOC over the last 150 years of the simulation (Fig. 3). This feature indicates that the AMOC was close to equilibrium at the end of the $126 \mathrm{ka}$ simulation and makes possible the comparison of the three experiments. 
Table 3. Characteristics of the four IPSL-CM4 model simulations considered in this study. The simulations are forced with the modern ice sheet configuration.

\begin{tabular}{lllll}
\hline & $126 \mathrm{ka}$ & $122 \mathrm{ka}$ & $115 \mathrm{ka}$ & $126 \mathrm{ka}$ meltwater \\
\hline Eccentricity $\left(^{\circ}\right)$ & 0.0397 & 0.0407 & 0.0414 & 0.0397 \\
Obliquity $\left(^{\circ}\right)$ & 23.9 & 23.2 & 22.4 & 23.9 \\
Precession $\left(\omega-180^{\circ}\right)$ & 201 & 356 & 111 & 201 \\
$\mathrm{CO}_{2}$ (ppmv) & 280 & 280 & 280 & 280 \\
$\mathrm{CH}_{4}$ (ppbv) & 650 & 650 & 650 & 650 \\
$\mathrm{~N}_{2} \mathrm{O}$ (ppbv) & 270 & 270 & 270 & 270 \\
Interactive meltwater & & & & 0.17 \\
input (Sv) & & Braconnot et al. (2008) & Braconnot et al. (2008) & Swingedouw et al. (2007b, 2009) \\
Reference & Braconnot et al. (2008) & &
\end{tabular}

${ }^{*}$ The simulation at $122 \mathrm{ka}$ contains a small input of freshwater $(0.03 \mathrm{~Sv})$, which has a very limited impact on deep-water formation.

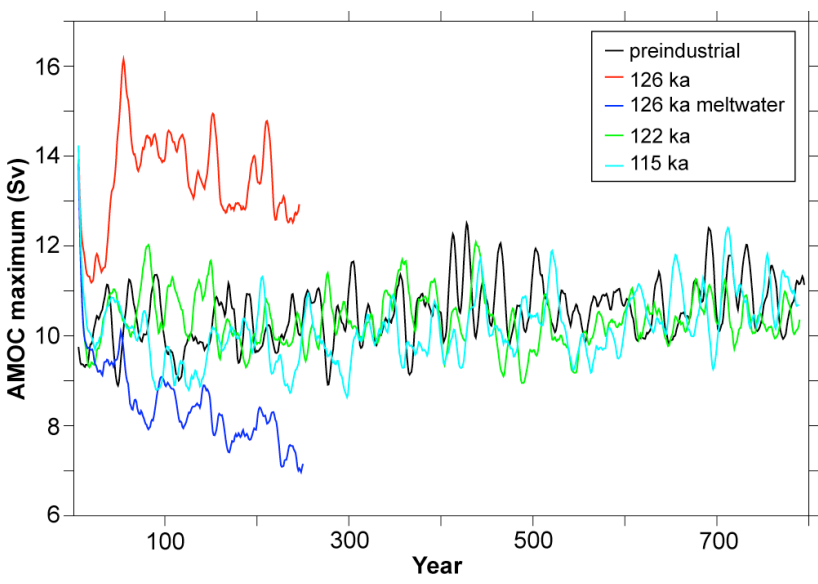

Fig. 3. Maximum of the Atlantic meridional overturning streamfunction $\left(1 \mathrm{~Sv}=10^{6} \mathrm{~m}^{3} \mathrm{~s}^{-1}\right)$ taken from $500 \mathrm{~m}$ to the bottom for all simulations: preindustrial (black), $126 \mathrm{ka}$ (red), $126 \mathrm{ka}$ meltwater (blue), $122 \mathrm{ka}$ (green) and $115 \mathrm{ka}$ (turquoise).

Second, to investigate the influence of a northern meltwater input on high-latitude climate during the early LIG, we consider two simulations at $126 \mathrm{ka}$. In addition to the $126 \mathrm{ka}$ simulation described above, which integrates the direct climatic response to insolation forcing at $126 \mathrm{ka}$ (Braconnot et al., 2008), we add the response of ice caps (here the melting of Greenland) in a second simulation called " 126 ka meltwater" (250 year-long simulation) (Table 3 ). We used the simple parameterization developed for future climate (Swingedouw et al., 2007b, 2009). The novelty here, when compared to classical freshwater experiments, is that (1) the influence of the specific $126 \mathrm{ka}$ insolation values on the LIG climate is taken into account, and (2) the meltwater flux is interactive with climate (Swingedouw et al., 2007b, 2009). In response to the high boreal summer insolation at $126 \mathrm{ka}$, about $0.17 \mathrm{~Sv}$ freshwater flux is redistributed in the North Atlantic north of $40^{\circ} \mathrm{N}$. Because this number is high as compared to other estimates (Otto-Bliesner et al., 2006), the "126 ka meltwater" simulation represents the highest effect that a meltwater pulse could have on high northern latitude climate during the early LIG and does not pretend to represent the real climate at $126 \mathrm{ka}$ (see Sect. 4.3.2).

\section{Marine records: evolution of the LIG climate}

\subsection{Establishment of the interhemispheric time frame}

The definition of reliable chronologies is critical to compare the LIG climate evolution indicated by records from different water depths and oceanic basins. Direct correlation of the plateau of benthic $\delta^{18} \mathrm{O}$ minimum values (hereafter called benthic O-plateau) is commonly applied during the LIG (e.g. Cortijo et al., 1999). Benthic $\delta^{18} \mathrm{O}$ data however do not only reflect global ice volume variations because they are also affected by deep-water temperature changes (e.g. Skinner and Shackleton, 2005), the presence of ${ }^{18} \mathrm{O}$-depleted deep waters in the Nordic Seas (e.g. Dokken and Jansen, 1999; Risebrobakken et al., 2006; Bauch and Erlenkeuser, 2008), that may reach the deep North Atlantic (Labeyrie et al., 2005; Waelbroeck et al., 2006, 2011), and/or the injection of ${ }^{18} \mathrm{O}$-depleted meltwater (Ganopolski and Roche, 2009). We prefer to develop here a common time frame between sediment cores from the Labrador and Norwegian Seas, the North Atlantic and Southern Ocean during the LIG that is independent from benthic isotope stratigraphy (e.g. Skinner et al., 2010; Waelbroeck et al., 2011). We transfer the marine sediment records on one single time scale, and use the most recent (EDC3) chronology available for the Antarctic EPICA Dome $\mathrm{C}$ (EDC) and Dronning Maud Land (EDML) ice cores during the LIG (Loulergue et al., 2007; Parrenin et al., 2007; Ruth et al., 2007). This chronology has been extended to the Greenland ice core at NorthGRIP (North Greenland Ice Core Project members, 2004) during the LIG, using global atmospheric markers (Capron et al., 2010). 


\subsubsection{Age models of the Southern Ocean and North Atlantic cores}

To transfer the Southern Ocean and North Atlantic records on this timescale, we assume that surface-water temperature changes in the subantarctic zone of the Southern Ocean (respectively in the North Atlantic) occurred simultaneously with air temperature variations over inland Antarctica (respectively Greenland). This has in particular been observed during the last glacial period and Termination I (e.g. Bond et al., 1993; Calvo et al., 2007).

\section{Southern Ocean core}

We tied the SST record from core MD02-2488 to the deuterium record from the EDC ice core (Jouzel et al., 2007). Because the SST resolution of the Southern Ocean core has been increased since the publication by Govin et al. (2009), we adjusted the original age model by up to $2 \mathrm{ka}$ during the LIG period. Figure 4 presents the new age model. The tie-points defined and associated age uncertainties are given in Table 4. Tie-points are defined as follows. We synchronized the first increase in SST and deuterium recorded in the marine and ice cores at the beginning of Termination II (Fig. 4). The accelerated temperature increases observed between small "temperature plateaux" in EDC deuterium record during Termination II are tied to similar events recorded in core MD02-2488 (Fig. 4). We synchronized the SST and deuterium maxima from the marine and ice cores at the beginning of the LIG, and the beginning of the SST and deuterium decrease from both cores at the end of the LIG (Fig. 4). Finally, the age model during the last glacial inception relies on three tie-points: at the midpoint, by the temperature minimum preceding the warm phase of DansgaardOeschger $(\mathrm{D} / \mathrm{O})$ event 25 , and by the temperature minimum defined between the warm phases of D/O 25 and 24 (Fig. 4).

\section{North Atlantic cores}

We synchronized the SST proxy records from the North Atlantic cores ODP 980, MD95-2042 and CH69-K09 to the ice $\delta^{18} \mathrm{O}$ record from the NGRIP Greenland ice core during the last glacial inception (Fig. 5). Note that the planktic Globigerina bulloides $\delta^{18} \mathrm{O}$ record is a good proxy of SST in core MD95-2042 (Shackleton et al., 2000). However, the Greenland ice core starts at $122 \mathrm{ka}$ and does not cover the early LIG (North Greenland Ice Core Project members, 2004). Past records from the Greenland ice cores indicate that abrupt Greenland warming phases during the glacial millennialscale Dansgaard-Oeschger events and Termination I are in phase with sharp methane increases (e.g. Chappellaz et al., 1993; Severinghaus and Brook, 1999; Flückiger et al., 2004; Huber et al., 2006). Here we assume that similarly, the abrupt warming of the air above Greenland during Termination II is synchronous with the global abrupt methane in-

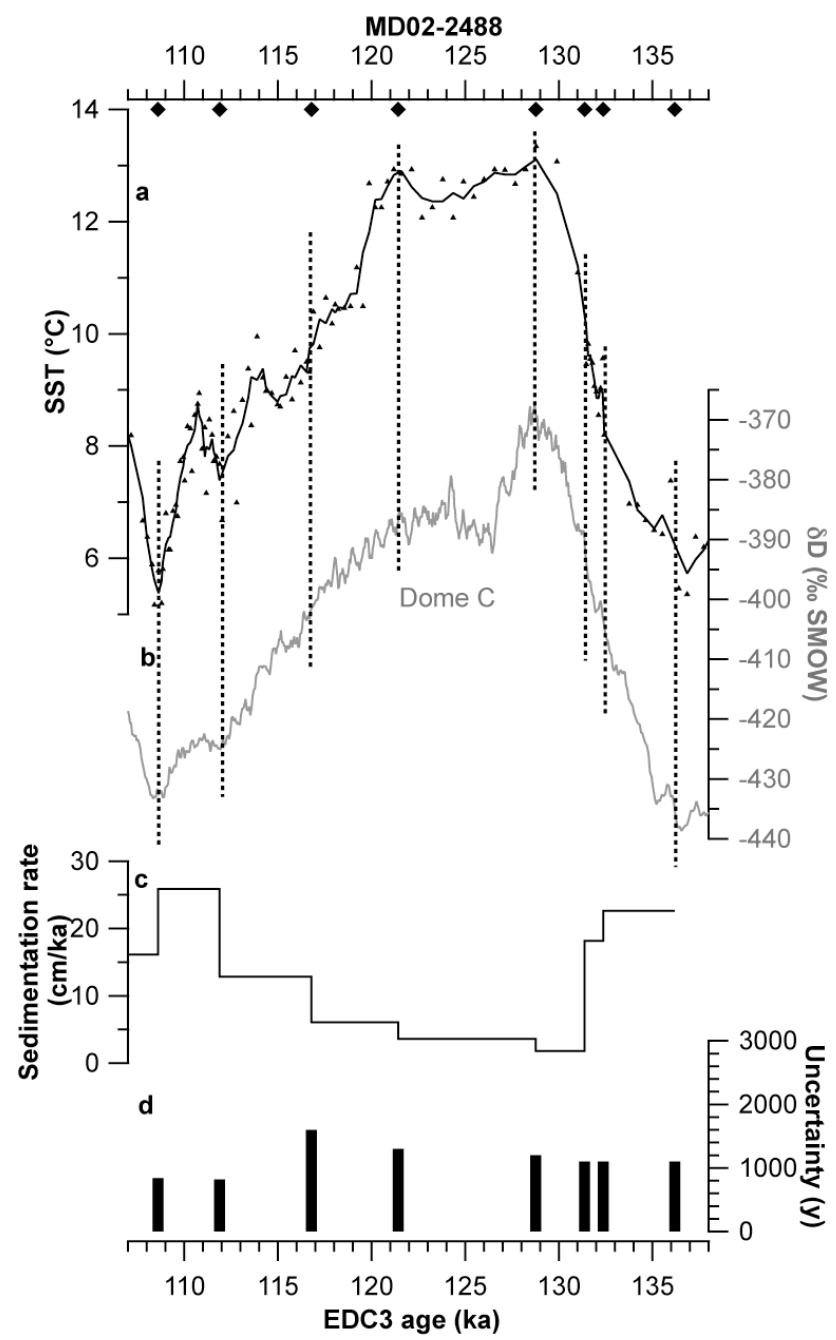

Fig. 4. Definition of the age model of core MD02-2488 from the Southern Ocean. (a) Sea surface temperature (3-point smoothing curve, black line) from core MD02-2488 (Govin et al., 2009). Diamonds and vertical dotted lines highlight the tie-points. (b) Antarctic EDC $\delta$ D record (EPICA Community members, 2004; Jouzel et al., 2007) (5-point smoothing curve, grey line). (c) Sedimentation rate variations in core MD02-2488. (d) Age uncertainty of the tiepoints defined between core MD02-2488 and EDC ice core (see Table 4 for details).

crease recorded in the Antarctic ice core (Loulergue et al., 2008). This hypothesis reflects the major methane emissions by boreal wetlands that resulted from Northern Hemisphere warming and ice sheet retreat associated with the terminations of the last $800 \mathrm{ka}$ (Loulergue et al., 2008). Therefore, we tied (1) the North Atlantic warming indicated by SST proxy records to the EDC methane increase during Termination II, and (2) North Atlantic SST variations to NGRIP ice $\delta^{18} \mathrm{O}$ record at the end of the LIG (Fig. 5). We defined all tie-points as follows (Table 4). At the beginning of the LIG, the final SST increase recorded in the marine cores 
Table 4. Tie-points defined in each sediment core and relative age uncertainties ( $1 \sigma$, in years) on the EDC 3 time scale. The total age uncertainty (last column of the table) is derived from the quadratic sum of individual uncertainties ${ }^{\mathrm{a}}$.

\begin{tabular}{|c|c|c|c|c|c|c|c|c|c|}
\hline Core & $\begin{array}{l}\text { Depth } \\
(\mathrm{cm})\end{array}$ & $\begin{array}{l}\text { EDC3 } \\
\text { age } \\
\text { (ka) }\end{array}$ & Rational & $\begin{array}{l}\text { Resolution of } \\
\text { correlated } \\
\text { record }(y)\end{array}$ & $\begin{array}{r}\text { Resolution } \\
\text { of reference } \\
\text { record }(y)\end{array}$ & $\begin{array}{r}\text { Matching } \\
\text { uncertainty } \\
(y)\end{array}$ & $\begin{array}{l}\text { Uncertainty on } \\
\text { the transfer of } \\
\text { NGRIP on } \\
\text { EDC3 time } \\
\text { scale }^{\mathrm{b}}(y)\end{array}$ & $\begin{array}{l}\text { Uncertainty } \\
\text { on the gas- } \\
\text { ice age } \\
\text { difference } \\
\text { of } \operatorname{EDC}^{\mathrm{c}}(y)\end{array}$ & $\begin{array}{r}\text { Total age } \\
\text { uncertainty } \\
\text { on EDC3 } \\
\text { time scale }(y)\end{array}$ \\
\hline \multicolumn{10}{|c|}{ Southern Ocean } \\
\hline \multirow[t]{8}{*}{ MD02-2488 } & 2346.1 & 108.6 & $\begin{array}{l}\text { Temperature minimum } \\
\text { between } \mathrm{D} / \mathrm{O} 24 \text { and } \mathrm{D} / \mathrm{O} 25\end{array}$ & 240 & 73 & 800 & & & 840 \\
\hline & 2431.3 & 111.9 & $\begin{array}{l}\text { Temperature minimum } \\
\text { preceding D/O } 25\end{array}$ & 150 & 70 & 800 & & & 820 \\
\hline & 2494.3 & 116.8 & Midpoint of temperature decrease & 210 & 58 & 1200 & & & 1300 \\
\hline & 2522.4 & 121.4 & Beginning of temperature decrease & 400 & 47 & 1200 & & & 1300 \\
\hline & 2549.0 & 128.8 & Temperature maxima & 560 & 32 & 1000 & & & 1200 \\
\hline & 2553.7 & 131.4 & Enhanced rate of temperature change & 450 & 43 & 1000 & & & 1100 \\
\hline & 2571.6 & 132.4 & Enhanced rate of temperature change & 100 & 56 & 1000 & & & 1100 \\
\hline & 2658.1 & 136.2 & Beginning of temperature increase & 440 & 101 & 1000 & & & 1100 \\
\hline \multicolumn{10}{|c|}{ North Atlantic } \\
\hline \multirow[t]{3}{*}{ ODP 980} & 1436.9 & 112.4 & Temperature increase of D/O 25 & 130 & 50 & $1000^{\mathrm{d}}$ & $1400^{\mathrm{b}}$ & & 1800 \\
\hline & 1504.1 & 116.1 & Temperature decrease during C26 & 220 & 80 & $1000^{\mathrm{d}}$ & $1400^{\mathrm{b}}$ & & 1800 \\
\hline & 1726.8 & 128.8 & $\begin{array}{l}\text { Final abrupt warming and } \mathrm{CH}_{4} \\
\text { increase }\end{array}$ & 350 & 170 & $400^{\mathrm{e}}$ & & 400 & 700 \\
\hline \multirow[t]{4}{*}{ MD95-2042 } & 2438.9 & 112.4 & Temperature increase of D/O 25 & 450 & 50 & $500^{\mathrm{d}}$ & $1400^{\mathrm{b}}$ & & 1600 \\
\hline & 2486.0 & 116.1 & Temperature decrease during C26 & 460 & 80 & $1000^{\mathrm{d}}$ & $1400^{\mathrm{b}}$ & & 1800 \\
\hline & 2570.0 & 128.8 & $\begin{array}{l}\text { Final abrupt warming and } \mathrm{CH}_{4} \\
\text { increase }\end{array}$ & 380 & 170 & $400^{\mathrm{e}}$ & & 400 & 700 \\
\hline & 2650.5 & 131.8 & Start of warming and $\mathrm{CH}_{4}$ increase & 360 & 280 & $1500^{\mathrm{e}}$ & & 400 & 1700 \\
\hline \multirow[t]{4}{*}{ CH69-K09 } & 1138.7 & 109.4 & $\begin{array}{l}\text { Temperature decrease } \\
\text { following } \mathrm{D} / \mathrm{O} 25\end{array}$ & 800 & 45 & $1000^{\mathrm{d}}$ & $1400^{\mathrm{b}}$ & & 1900 \\
\hline & 1181.1 & 116.2 & Temperature decrease during C26 & 800 & 80 & $1000^{\mathrm{d}}$ & $1400^{\mathrm{b}}$ & & 1900 \\
\hline & 1268.8 & 128.8 & $\begin{array}{l}\text { Final abrupt warming and } \mathrm{CH}_{4} \\
\text { increase }\end{array}$ & 750 & 170 & $400^{\mathrm{e}}$ & & 400 & 1000 \\
\hline & 1293.6 & 132.5 & Benthic $\delta^{18} \mathrm{O}$ decrease & 750 & 340 & 1000 & $1700^{\mathrm{f}}$ & & 2200 \\
\hline \multicolumn{10}{|c|}{ Norwegian Sea } \\
\hline \multirow[t]{2}{*}{ MD95-2010 } & 1246.1 & 116.1 & Temperature decrease & 520 & 80 & 1500 & $1400^{\mathrm{b}}$ & & 2200 \\
\hline & 1260.4 & 128.8 & Beginning of benthic O-plateau & 2000 & 720 & 1000 & $700^{\mathrm{f}}$ & & 2500 \\
\hline \multicolumn{10}{|c|}{ Labrador Sea } \\
\hline \multirow[t]{2}{*}{ EW9302-JPC2 } & 782.8 & 116.1 & Temperature decrease & 800 & 80 & 1500 & $1400^{\mathrm{b}}$ & & 2300 \\
\hline & 839.3 & 128.8 & Diatom mat and $\mathrm{CH}_{4}$ increase & $1500^{\mathrm{g}}$ & 170 & $1500^{\mathrm{e}}$ & & 400 & 2200 \\
\hline
\end{tabular}

${ }^{a}$ The total age uncertainty combines: (1) the resolution of correlated record (for example, the SST record from core MD02-2488, or the planktic $\delta^{18} \mathrm{O}$ record from core MD95-2042); (2) the resolution of the reference record (e.g. $\delta \mathrm{D}$ or methane records from the EDC ice core, ice $\delta^{18} \mathrm{O}$ record from NGRIP ice core); (3) the uncertainty derived from the matching procedure (graphically estimated when defining the tie-points with the Analyseries software, Paillard et al., 1996); and (4) for sediment cores from high northern latitudes only, the age uncertainty on the transfer of NGRIP record on EDC3 time scale (Capron et al., 2010) or the age uncertainty on the gas-ice age difference in EDC ice core (Loulergue et al., 2007).

${ }^{\mathrm{b}}$ Capron et al. (2010)

${ }^{\mathrm{c}}$ Loulergue et al. (2008)

${ }^{\mathrm{d}}$ For these tie-points, the North Atlantic records have been correlated to the ice $\delta^{18} \mathrm{O}$ record from the Greenland NGRIP ice core.

${ }^{\mathrm{e}}$ For these tie-points, the North Atlantic records have been correlated to the methane record from the Antarctic EDC ice core.

${ }^{\mathrm{f}}$ Because these tie-points have been respectively defined by correlation to the benthic $\delta^{18} \mathrm{O}$ record from core MD95-2042 and ODP 980, their age uncertainties are those of cores MD95-2042 and ODP 980 on EDC3 time scale over the corresponding intervals.

g Uncertainty on the upper limit of the diatom layer in the Labrador Sea core.

is synchronized to the abrupt methane increase recorded in the Antarctic ice core (Fig. 5). At the end of the LIG, the first pronounced North Atlantic cooling (related to the cold event 26, Oppo et al., 2006) is tied to the corresponding enhanced cooling recorded in the Greenland ice core (Fig. 5). We finally synchronized surface-water and air temperature changes at the beginning or the end of D/O 25 during the last glacial inception (Fig. 5). Altogether the three North Atlantic cores present, within age uncertainties (Table 4), consistent benthic $\delta^{18} \mathrm{O}$ variations during the period $135-110 \mathrm{ka}$ (see Fig. 8). 


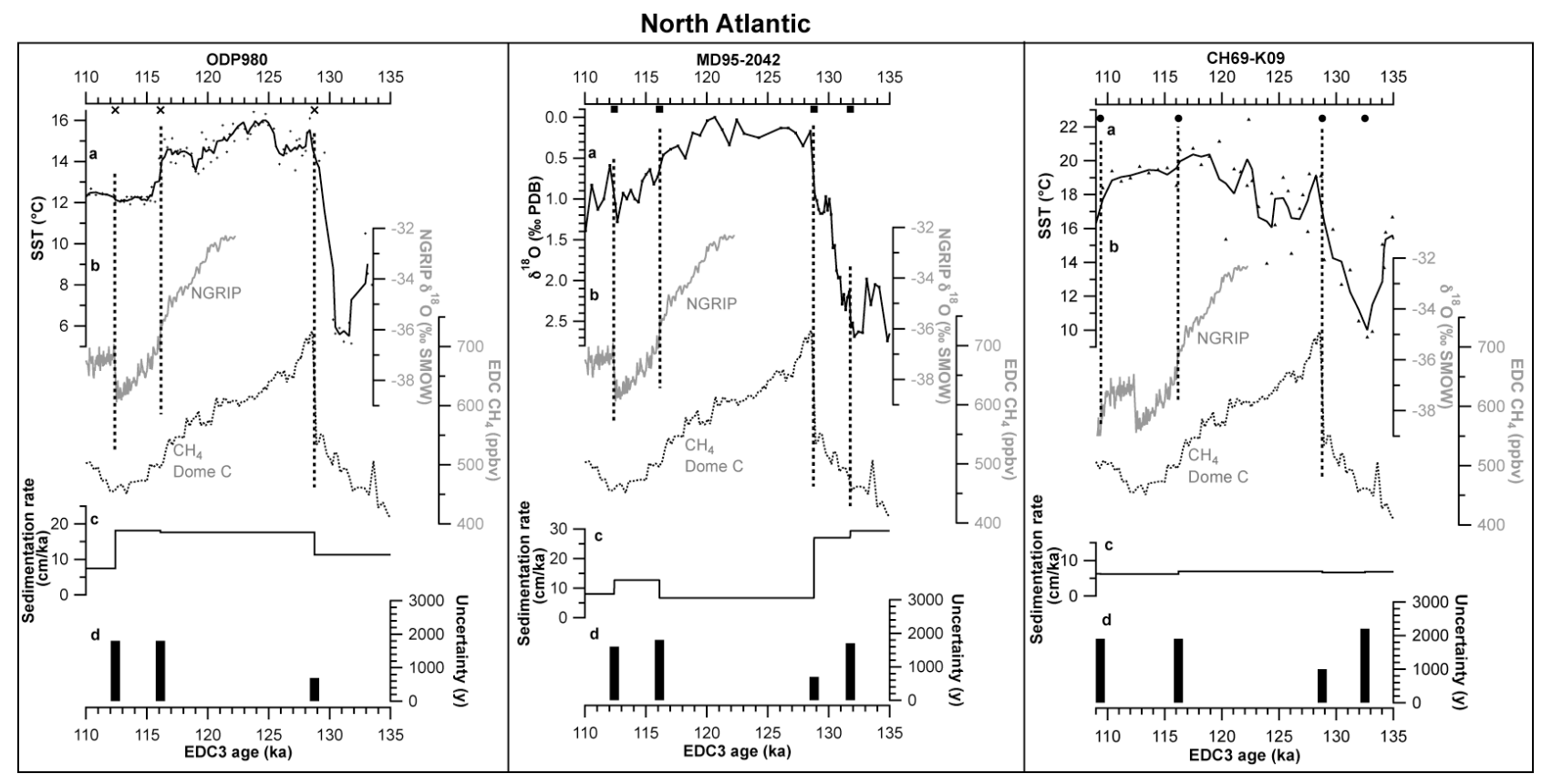

Fig. 5. Definition of the age model of the three sediment cores from the North Atlantic. (a) (left panel) Sea surface temperature (3-point smoothing curve, black line) from core ODP 980 (Oppo et al., 2006); (mid panel) planktic $\delta^{18} \mathrm{O}$ record (black line) from core MD95-2042 (Shackleton et al., 2002); (right panel) Sea surface temperature (3-point smoothing curve, black line) from core CH69-K09 (Cortijo et al., 1999). (b) (all panels) Greenland NGRIP ice $\delta^{18}$ O record (North Greenland Ice Core Project members, 2004) (grey line) and Antarctic EDC methane record (Loulergue et al., 2008) (grey dotted line). (c) (all panels) Sedimentation rate variations. (d) (all panels) Age uncertainty of the defined tie-points (see Table 4 for details). Tie-points are indicated by symbols (crosses for core ODP 980, left panel; squares for core MD95-2042, mid panel; circles for core CH69-K09, right panel) and highlighted by the vertical dotted lines.

The relative age uncertainty of the Southern Ocean records on EDC3 time scale is estimated to be at the most $\pm 1.3 \mathrm{ka}$ $(1 \sigma)$ (Table 4). Similarly, the maximum age uncertainty on North Atlantic records on EDC3 time scale reaches $\pm 2.2 \mathrm{ka}$ $(1 \sigma)$. These uncertainties integrate (1) the resolution of correlated records in marine sediment cores, (2) the resolution of ice core reference records, (3) a matching uncertainty graphically estimated when defining the tie-points, and (4) for Northern Hemisphere records only, the relative uncertainty on ice core chronologies (i.e. on the transfer of NGRIP record on EDC3 time scale or on the gas-ice age difference in EDC ice core). Details on tie-points and age uncertainties are given in Table 4. The combined age uncertainty that needs to be considered when comparing Southern Ocean to North Atlantic records reaches at the most $\pm 2.6 \mathrm{ka}(1 \sigma)$ over the period 130-115 ka. Within this time frame, the benthic Oplateau, which marks interglacial periods in marine sediment cores (Shackleton, 1969), starts at around $130.0 \mathrm{ka}( \pm 0.6 \mathrm{ka})$ in the North Atlantic, i.e. $3.5 \mathrm{ka}( \pm 2.6 \mathrm{ka})$ earlier than in the Southern Ocean (Figs. 7c and 8c). This offset is consistent with time-lags observed within the deep ocean during deglaciations (Bard et al., 1991; Skinner and Shackleton, 2005; Ganopolski and Roche, 2009).

\subsubsection{Age models of the Labrador Sea and Norwegian Sea cores}

Defining reliable chronologies to sediment cores from the Labrador and Norwegian Seas is delicate. First, during glacial times, the temperature of surface waters can fall below $3{ }^{\circ} \mathrm{C}$ in the Nordic Seas (e.g. during the Last Glacial Maximum, Meland et al., 2005; MARGO Project Members, 2009). However, the percentage of N. pachyderma sinistral, which dominates foraminifera faunal assemblages during cold periods, do not record SST variations below $6.5^{\circ} \mathrm{C}$ (Fig. 1). The beginning and the amplitude of the warming during Termination II are hence not well recorded by $N$. pachyderma percentages in the Labrador and Norwegian Seas. Second, foraminiferal $\delta^{18} \mathrm{O}$ records that are affected by large ${ }^{18} \mathrm{O}$-depleted meltwater pulses during Termination II (e.g. Risebrobakken et al., 2006; Bauch and Erlenkeuser, 2008) must be considered with care. We combine several lines of evidence to define the LIG chronologies of the Labrador Sea and Norwegian Sea cores.

\section{Labrador Sea core}

To define the age model of core EW9302-JPC2 (Fig. 6, left panel), we tied at the end of the LIG the midpoint 

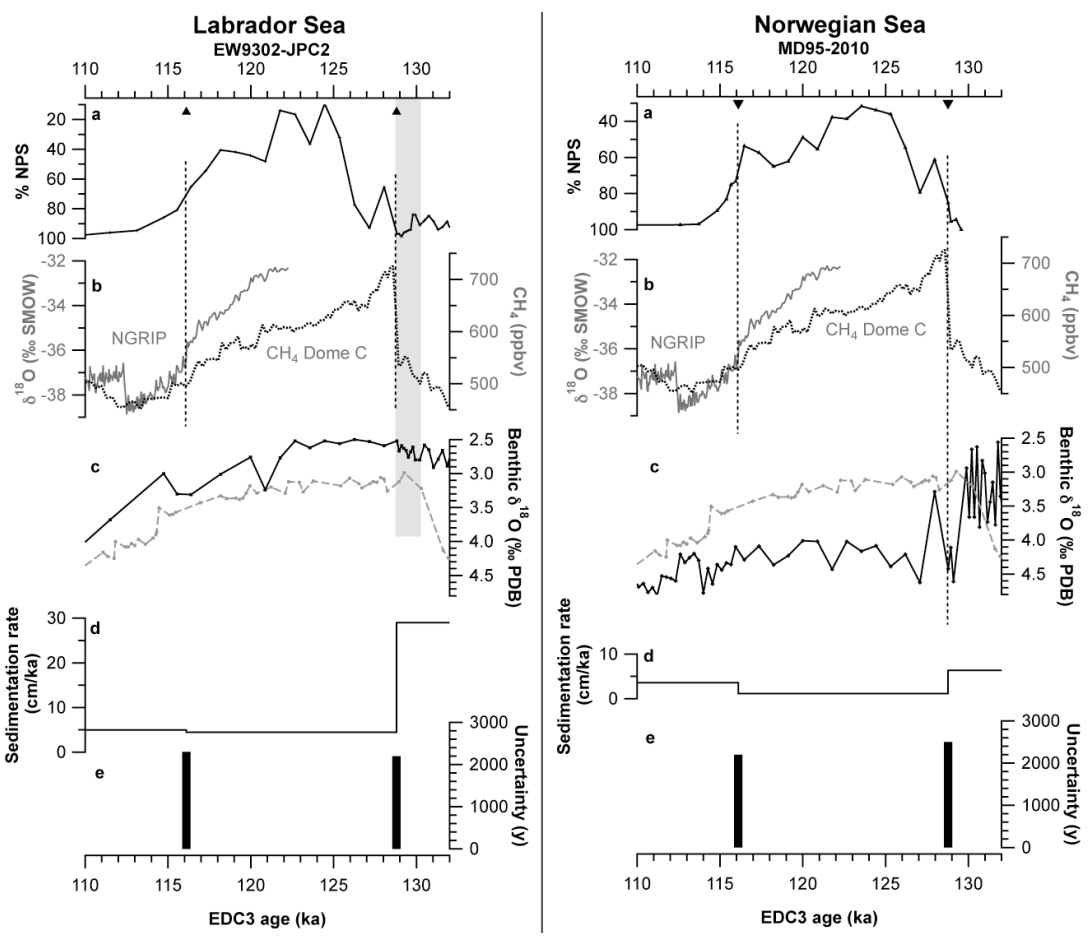

Fig. 6. Definition of the age model of the two cores from the Labrador Sea (left panel) and the Norwegian Sea (right panel). (a) Percentage of the polar species N. pachyderma sinistral (\% NPS) (black line) from (left panel) core EW9302-JPC2 from the Labrador Sea (Rasmussen et al., 2003a), and (right panel) core MD95-2010 from the Norwegian Sea (Risebrobakken et al., 2005). (b) (all panels) Greenland NGRIP ice $\delta^{18} \mathrm{O}$ record (North Greenland Ice Core Project members, 2004) (grey line) and Antarctic EDC methane record (Loulergue et al., 2008) (grey dotted line). (c) Benthic $\delta^{18} \mathrm{O}$ record from (left panel) core EW9302-JPC2 (black line) (Rasmussen et al., 2003a) and from (right panel) core MD95-2010 (black line) (Risebrobakken et al., 2005), in comparison to the benthic $\delta^{18}$ O record of the North Atlantic core ODP 980 (grey dashed line) (Oppo et al., 2006). (d) (all panels) Sedimentation rate variations. (e) (all panels) Age uncertainty of the defined tie-points (see Table 4 for details). Tie-points are indicated by triangles in (a), and highlighted by the vertical dotted lines. The grey shaded area in the left panel highlights the diatom mat at the onset of the LIG (Rasmussen et al., 2003a).

of the cooling transition (indicated by increasing percentages of $N$. pachyderma sinistral) to the enhanced cooling recorded in NGRIP $\delta^{18} \mathrm{O}$ record (Fig. 6a-b). Consistent benthic $\delta^{18} \mathrm{O}$ variations in the Labrador Sea and North Atlantic after $\sim 120$ ka supports this tie-point (Fig. 6c). Furthermore, the upper limit of diatom layers marks the onset of the Holocene and of the LIG (grey-shaded area in Fig. 6) in core EW9302-JPC2 (Rasmussen et al., 2003a). Such diatom mats are associated to major deglacial transitions in the North Atlantic (Jennings et al., 1996) and observed at the beginning of MIS 5 and 1 in the Norwegian Sea (Koç Karpuz and Jansen, 1992; Rasmussen et al., 1999). We hence assume here that the top of the diatom layer in the Labrador Sea core occurs in phase with the LIG establishment of warm conditions in the North Atlantic, which is highlighted by the sharp methane increase at $129 \mathrm{ka}$ (Fig. 6, Table 4). To support this tie-point, the deglacial melting signal indicated by low benthic $\delta^{18} \mathrm{O}$ values during Termination II (Rasmussen et al., 2003a) ends, within age uncertainties, at the beginning of the North Atlantic benthic O-plateau (Fig. 6). The abrupt methane increase is then synchronous with the first decrease in N. pachyderma percentages recorded in the Labrador Sea core. Because the temperature sensitivity of this proxy is low at low temperatures (Fig. 1), the beginning and amplitude (at least $2^{\circ} \mathrm{C}$ ) of this first surface-water warming in the Labrador Sea are imprecise. Thus, the definition of this time-point remains consistent with our assumption of synchronous high northern latitude warming and methane increase during Termination II. Following this hypothesis, one could alternatively decide to correlate the sharp methane increase at $129 \mathrm{ka}$ to the decrease in $N$. pachyderma percentages around $126 \mathrm{ka}$ in our chronology (Fig. 6). We dismiss this alternative age model for two reasons. First, it would require shifting the diatom layer to $132 \mathrm{ka}$, i.e. at a time when glacial thermal conditions were dominant in the North Atlantic (Fig. 5). This feature clearly contradicts the occurrence of thick diatom mats at the onset of the Holocene and LIG in the Labrador/Norwegian Sea (Koç Karpuz and Jansen, 1992; Jennings et al., 1996; Rasmussen et al., 1999). Second, it would require shifting the beginning of the benthic O-plateau at $132 \mathrm{ka}$ in the Labrador Sea. At this time, North Atlantic benthic $\delta^{18} \mathrm{O}$ values were $1.2 \%$ o higher than during 
the LIG plateau. Even integrating deep-water temperature changes, this $\delta^{18} \mathrm{O}$ difference implies a significant sea level increase (several dozen meters). Stable benthic $\delta^{18} \mathrm{O}$ values in the Labrador Sea from $132 \mathrm{ka}$ on would require a very large amount of freshwater to compensate for this remaining sea level increase. IRD data however indicate that the meltwater supply was already significantly reduced at the beginning of the benthic O-plateau in the Labrador/Norwegian Sea (Fig. 7a). Altogether, these arguments make this alternative chronology very unlikely.

\subsubsection{Norwegian Sea core}

Similarly to the Labrador Sea core, we tied at the end of the LIG the midpoint of the cooling recorded by increasing percentages of $N$. pachyderma sinistral in the Norwegian Sea core MD95-2010 to the enhanced cooling recorded in NGRIP $\delta^{18} \mathrm{O}$ record (Fig. 6, right panel). A simultaneous increase (within age uncertainties) in benthic $\delta^{18} \mathrm{O}$ records from the Norwegian Sea and the North Atlantic after $\sim 120 \mathrm{ka}$ (Fig. 6c) supports this tie-point. At the beginning of the LIG, we defined the tie-point so that the deglacial melting signal indicated by low Norwegian Sea benthic $\delta^{18} \mathrm{O}$ values during Termination II (Risebrobakken et al., 2006; Bauch and Erlenkeuser, 2008) ended when the benthic Oplateau started in the North Atlantic (Fig. 6). $\delta^{18} \mathrm{O}$ values of the LIG benthic plateau are about $1 \%$ higher in the Norwegian Sea than in the North Atlantic (Fig. 6, Table 4). This feature is consistent with Norwegian Sea deep waters being colder by 3 to $4{ }^{\circ} \mathrm{C}$ than North Atlantic deep waters during interglacials (Labeyrie et al., 1987). The abrupt methane increase at $129 \mathrm{ka}$ then occurred in phase with the first Norwegian Sea surface-water warming indicated by the decrease in $N$. pachyderma percentages. We just reported this feature in the Labrador Sea. It highlights our assumption of simultaneous methane increase and high northern latitude warming during Termination II and supports the definition of this tie-point. As a result, surface waters from the Norwegian Sea and the Labrador Sea show a similar thermal evolution throughout the LIG (Fig. 7b). The warming indicated by the large decrease in $N$. pachyderma percentages in the Norwegian/Labrador Sea lags by 3-4 ka the North Atlantic deglacial warming (Fig. 7d). Based on the identification of a common ash layer (at $127 \mathrm{ka}$ ) in two cores north and south of Iceland, Rasmussen et al. (2003b) document the same late LIG warming in the Norwegian Sea in comparison to the North Atlantic. The poor planktic $\delta^{18} \mathrm{O}$ resolution and lack of benthic foraminifera for stable isotope analyses in the North Atlantic core used by Rasmussen et al. (2003b) prevent us from providing here additional constraints on the chronology of the Norwegian Sea core MD95-2010. The study by Rasmussen et al. (2003b) nevertheless supports with a robust tephra tie-point the chronostratigraphical approach that we developed here in the Norwegian Sea and Labrador Sea cores.

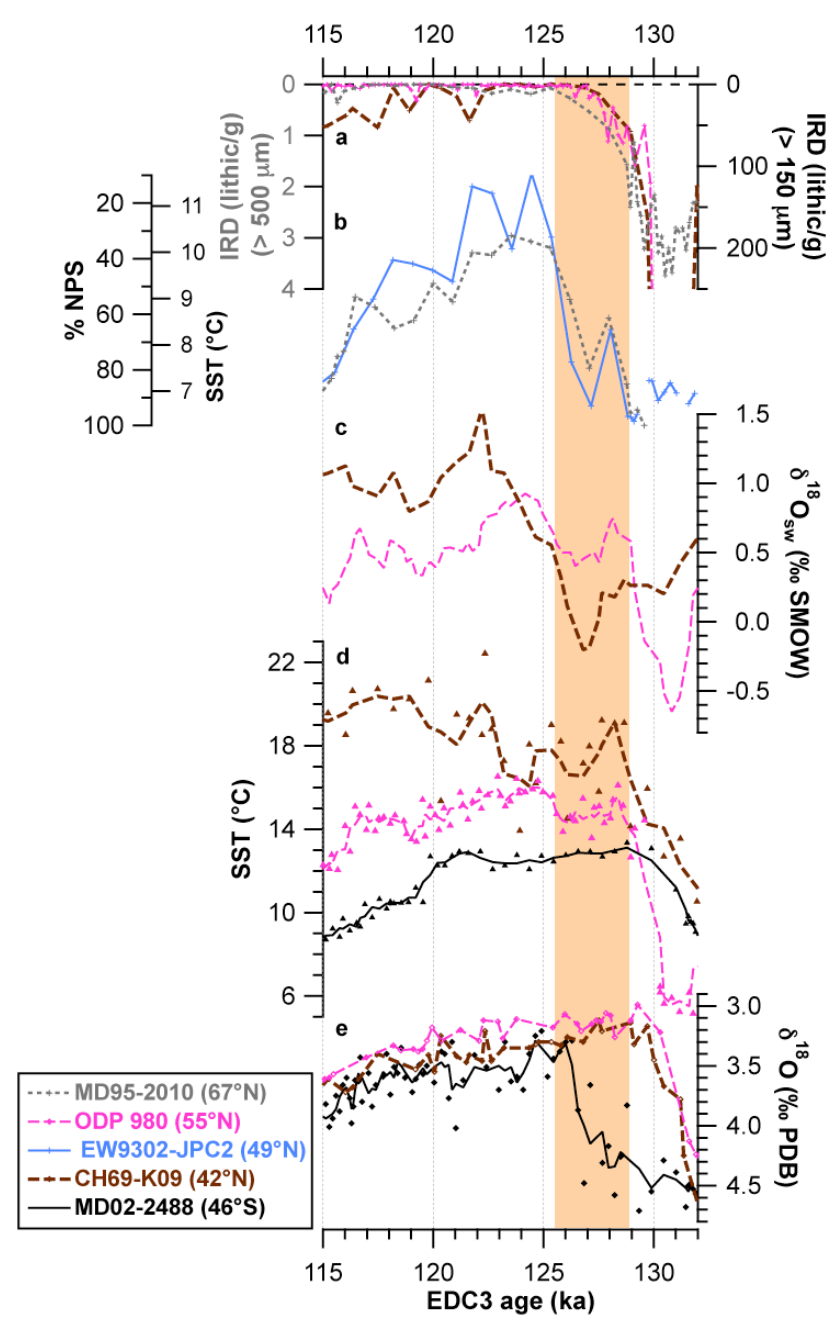

Fig. 7. Foraminiferal surface-water data over the period 132$115 \mathrm{ka}$. (a) IRD, (b) percentage of the polar species N. pachyderma sinistral, (c) seawater $\delta^{18} \mathrm{O}\left(\delta^{18} \mathrm{O}_{\mathrm{sw}}\right)$, (d) summer SST and (e) benthic $\delta^{18} \mathrm{O}$ records from the North Atlantic cores ODP 980 (dashed pink line) (Oppo et al., 2006) and CH69-K09 (dashed brown line) (Cortijo et al., 1999), the Norwegian Sea core MD95-2010 (dotted grey line) (Risebrobakken et al., 2006), the Labrador Sea core EW9302-JPC2 (Rasmussen et al., 2003a) (blue line), and the Southern Ocean core MD02-2488 (black line) (Govin et al., 2009). SST and Southern Ocean benthic records are 3-points smoothing curves. Seawater $\delta^{18} \mathrm{O}$ records are 5-points smoothing curves (see Fig. 2). The orange-shaded area highlights the period $129-125 \mathrm{ka}$ of the early LIG (see text).

The age uncertainties on the EDC3 time scale are estimated to be $\pm 2.3 \mathrm{ka}$ and $\pm 2.5 \mathrm{ka}(1 \sigma)$ in the Labrador Sea and the Norwegian Sea respectively over the period 130$115 \mathrm{ka}$. Details on how these uncertainties are calculated are given in Table 4. The comparison of Norwegian/Labrador Sea records to North Atlantic records requires combining the uncertainties of both sets of archives on EDC3 time scale. The total uncertainty reaches at the most $3.1 \mathrm{ka}(1 \sigma)$ throughout the LIG. 


\subsection{Evidence for a global late LIG climatic optimum at high northern latitudes}

\subsubsection{Evolution of surface waters during the LIG}

The evolution of northern and southern surface-water conditions is reported in Fig. 7. The Southern Ocean core record indicates the establishment of peak interglacial SSTs at $130 \mathrm{ka}$ at high southern latitudes (Fig. 7b), i.e. immediately at the end of the deglacial warming recorded in southern subpolar waters during Termination II. In contrast, the SST reconstructions from subpolar regions show that peak interglacial SSTs occur at $125 \mathrm{ka}$ in the Labrador Sea and the Norwegian Sea (Fig. 7b). In the North Atlantic at $55^{\circ} \mathrm{N}$, the large deglacial surface-water warming associated with Termination II ends at $129 \mathrm{ka}$ (Fig. 7d). It is followed by relatively stable SSTs during around 3-4 ka and an additional warming of $2{ }^{\circ} \mathrm{C}$, which leads to maximal North Atlantic SST at $125 \mathrm{ka}$ (Fig. 7d). We finally observe a gradual increase in surface-water temperature at mid-latitudes $\left(42^{\circ} \mathrm{N}\right)$ in the North Atlantic during the LIG (Cortijo et al., 1999) (Fig. 7d). Therefore, SST records from the Labrador Sea, Norwegian Sea and high-latitude North Atlantic indicate the establishment of optimal thermal conditions at $125 \mathrm{ka}$ at high northern latitudes, i.e. $5 \mathrm{ka}( \pm 2.6 \mathrm{ka})$ after the beginning of peak interglacial SSTs in the Southern Ocean.

We hence identify at the beginning of the LIG benthic O-plateau, an interval lasting three to four thousands years (period 129-125 ka, hereafter called "early LIG") characterized by: (1) peak interglacial conditions in the Southern Hemisphere, and (2) high northern latitude surface waters colder than in the later part of the benthic O-plateau (period 125-119 ka, hereafter called "late LIG"). The late establishment of oceanic thermal conditions that we document at high northern latitudes seems a consistent feature of the LIG climatic evolution in the Norwegian Sea (Rasmussen et al., 2003b; Bauch and Erlenkeuser, 2008; Bauch et al., 2011; Van Nieuwenhove et al., 2011). Our results suggest that the LIG delay in peak interglacial warmth is not restricted to the Norwegian Sea and extended to the Labrador Sea and highlatitude North Atlantic. The establishment of warm surfacewater conditions at $125 \mathrm{ka}$ in the North Atlantic $\left(55^{\circ} \mathrm{N}\right)$ takes place in two phases. The high-amplitude $\left(9^{\circ} \mathrm{C}\right)$ deglacial warming between 131 and $129 \mathrm{ka}$ precedes a second warming of $2^{\circ} \mathrm{C}$ leading to optimal thermal conditions at $125 \mathrm{ka}$ (Fig. 7d). The relatively small amplitude of this additional warming probably explains why the LIG delay in peak interglacial warmth is not visible in lower-resolution records from the North Atlantic (Oppo et al., 2001; Rasmussen et al., 2003b; Kandiano et al., 2004; Bauch and Kandiano, 2007).

The late North Atlantic thermal optimum is associated with a delay in peak interglacial salinities in North Atlantic surface waters. Reconstructions of seawater $\delta^{18} \mathrm{O}$ (Fig. 7c) show peak surface-water $\delta^{18} \mathrm{O}$ values at around $122 \mathrm{ka}$ at $42^{\circ} \mathrm{N}$ in the North Atlantic. At $55^{\circ} \mathrm{N}$, high surface-water $\delta^{18} \mathrm{O}$ values similar to Holocene values mark the beginning of the LIG at $129 \mathrm{ka}$ (Fig. 7c). An additional increase in seawater $\delta^{18} \mathrm{O}$ of $0.5 \%$ however leads to the establishment of peak surface-water $\delta^{18} \mathrm{O}$ values at $55^{\circ} \mathrm{N}$ at $125 \mathrm{ka}$ only (Fig. 7c). North Atlantic surface waters are thus relatively fresher during the early LIG than during the late LIG (Fig. 7c). This feature is consistent with lower salinities recorded during the early LIG in the Norwegian Sea (Van Nieuwenhove and Bauch, 2008; Bauch et al., 2011).

Finally, IRD data indicate the persistence of iceberg melting until around $126 \mathrm{ka}$ in the North Atlantic and in the Norwegian Sea (Fig. 7a). This result is consistent with persistent IRD documented after Termination II on the Vøring Plateau in the Norwegian Sea (Van Nieuwenhove and Bauch, 2008). The disappearance of iceberg melting at $126 \mathrm{ka}$ coincides, within age uncertainties, with the latest estimates of the LIG sea level highstand registered by corals (Waelbroeck et al., 2008; Blanchon et al., 2009). Iceberg melting hence persists at high northern latitudes within the LIG benthic Oplateau recorded in North Atlantic and Southern Ocean cores (Fig. 7e). Available data do not allow us to assign the specific geographical origin of the icebergs. However, icebergs are probably released by the remnant melting of the Northern ice sheets (NIS), in particular the Eurasian Saalian ice sheet (Svendsen et al., 2004; Lambeck et al., 2006). Iceberg melting likely contributes to maintain the relatively colder and fresher surface-water conditions observed at high northern latitudes during the early LIG compared to the late LIG.

\subsubsection{Evolution of deep waters during the LIG}

These particular northern surface-water conditions during the early LIG have their counterpart at depth (Fig. 8). Benthic $\delta^{13} \mathrm{C}$ data reveal variations in deep-water ventilation patterns between the early and late LIG (Fig. 8b). In the Southern Ocean, the increase in benthic $\delta^{13} \mathrm{C}$ values by $0.8 \%$ during Termination II leads to benthic $\delta^{13} \mathrm{C}$ values around $-0.1 \%$ at the beginning of the LIG at $130 \mathrm{ka}$ (Fig. 8b). Although these values are slightly lower than the ones recorded at the Southern Ocean site during the early Holocene $(+0.2 \%)$, they indicate the presence of already well-ventilated bottom waters in the deep Southern Ocean during the early LIG compared to the penultimate glacial period. The increase in benthic $\delta^{13} \mathrm{C}$ values recorded during Termination II at different water depths in the North Atlantic lags by $\sim 3 \mathrm{ka}( \pm 2.6 \mathrm{ka})$ the benthic $\delta^{13} \mathrm{C}$ increase in the Southern Ocean (Fig. 8b). This feature suggests a delay in the deglacial reorganization of North Atlantic deep waters during Termination II (Oppo et al., 1997).

Only the shallowest North Atlantic core indicates the presence of well-ventilated waters at $2000 \mathrm{~m}$ at the beginning of the LIG around $128 \mathrm{ka}$ (Fig. $8 \mathrm{~b}$ ). During the interval $129-125 \mathrm{ka}$, this core exhibits $\delta^{13} \mathrm{C}$ values of $\sim 0.8 \%$, i.e. higher by $\sim 0.4 \%$ o than the two deepest North Atlantic sites (Fig. 8b). Such a strong $\delta^{13} \mathrm{C}$ gradient between North 


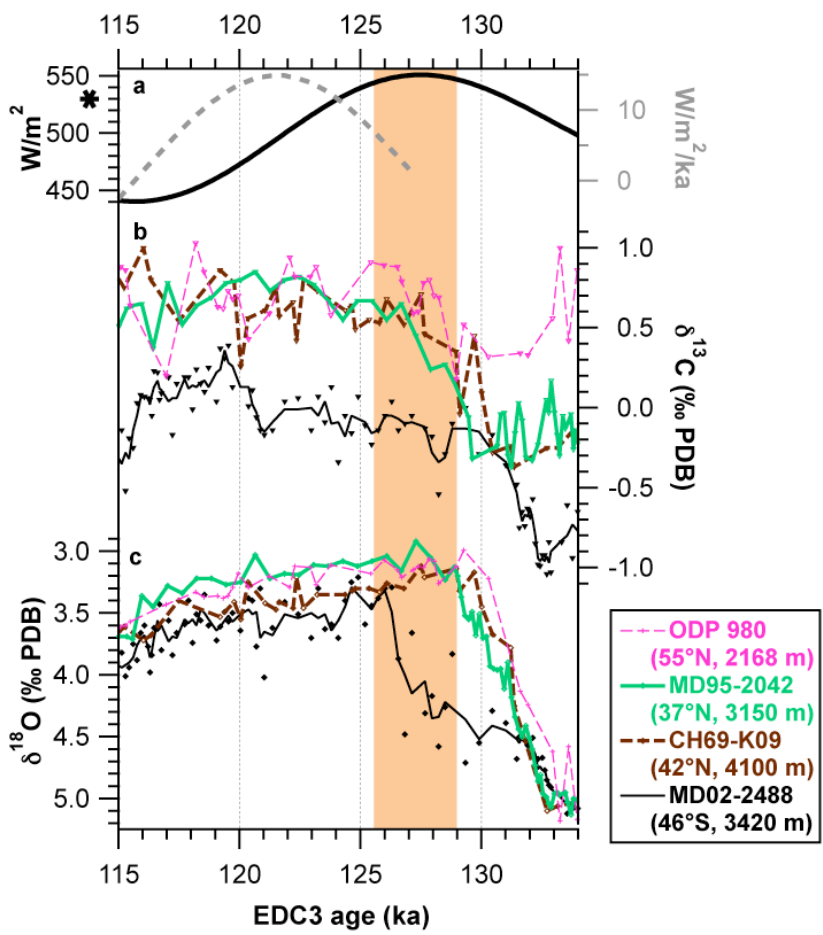

Fig. 8. Foraminiferal deep-water data over the period 134-115 ka. (a) 21 June insolation at $65^{\circ} \mathrm{N}$ (black line, Berger, 1978). Corresponding rate of insolation change (dashed grey line, right $\mathrm{y}$-axis) plotted for the period $127-115 \mathrm{ka}$ only. The star along the left y-axis indicates the insolation maximum at $11 \mathrm{ka}$. Benthic (b) $\delta^{13} \mathrm{C}$ (Cibicides) and (c) $\delta^{18} \mathrm{O}$ records from the North Atlantic cores ODP 980 (dashed pink line) (Oppo et al., 2006), MD95-2042 (green line) (Shackleton et al., 2002), CH69-K09 (dashed brown line) (Cortijo et al., 1999), and from the Southern Ocean core MD02-2488 (black line, 3-point smoothing curves) (Govin et al., 2009). The orangeshaded area highlights the period 129-125 ka of the early LIG (see text).

Atlantic intermediate and deep waters during the early LIG is supported by further data from the North Atlantic (Keigwin et al., 1994; Oppo et al., 1997; Hodell et al., 2009). This $\delta^{13} \mathrm{C}$ gradient reflects the persistent influence of bottom waters of southern origin in the deep North Atlantic during the early LIG (Oppo et al., 1997), i.e. the formation of a well-ventilated NADW that is less dense than during the late LIG. This feature is consistent with a weak North Atlantic deep-water circulation persistent at the beginning of the LIG on Gardar Drift (Iceland Basin) (Hodell et al., 2009). It is only during the late LIG, when the delivery of icebergs has ended and when northern surface waters are warm and saline (Fig. 7), that the deep ocean circulation becomes similar to the modern one. During that period, all North Atlantic cores between 2200 and $4100 \mathrm{~m}$ water depth exhibit high $\delta^{13} \mathrm{C}$ values around $0.8 \%$ (Fig. 8b). These $\delta^{13} \mathrm{C}$ values indicate the presence of the same water-mass, similar to the present-day high-ventilated NADW, between 2000 and $4000 \mathrm{~m}$ in the North Atlantic.
Our compilation of LIG data from the high northern and southern latitudes shows evidence for a persistent iceberg delivery at high northern latitudes during the early LIG. It is associated with relatively low salinity and temperature values in North Atlantic surface waters (Fig. 7), as well as a relatively weak ventilation of North Atlantic deep waters (Fig. 8) during the early LIG (129-125 ka) compared to the late LIG. The delay in peak interglacial warmth documented in the Norwegian Sea (Bauch and Erlenkeuser, 2008; Bauch et al., 2011; Van Nieuwenhove et al., 2011) hence affects the Labrador Sea and high-latitude North Atlantic regions and has its counterpart at depth. Oceanic conditions at high northern latitudes are hence intermediate between glacial and full interglacial conditions at the beginning of the LIG. They are in contrast with the Southern Ocean climate evolution, which exhibits maximum interglacial warmth and wellventilated bottom waters from the beginning of the LIG at $\sim 130 \mathrm{ka}$.

\section{Model-data comparison: possible climate processes responsible for the LIG climate evolution}

Delays in peak warmth conditions between the northern and southern high latitudes, similar to what we observe at the beginning of the LIG, are attributed to "bipolar seesaw" mechanisms during the last glacial period (e.g. Blunier and Brook, 2001). During Termination II, rapid northern ice sheet melting however suppressed the imprint of "bipolar seesaw" signals (northern temperature reversal) in climate records from the penultimate deglaciation (Ruddiman et al., 1980; Carlson, 2008). Boreal summer insolation values of the LIG exceed the early Holocene maximum value during $7 \mathrm{ka}$ at the beginning of the LIG (period 131-124 ka, Fig. 8a). In this section, we propose potential climate forcing and mechanisms responsible for the late LIG establishment of peak interglacial warmth and North Atlantic deep-water circulation. From the results of the model simulations, we investigate (1) to which extent high northern latitude climate solely responds to insolation variations during the LIG and (2) what the signature of a massive ice sheet melting would be during the early LIG.

\subsection{Oceanic response to insolation changes during the LIG}

We consider here the simulations performed with insolation as a sole forcing (Table 3): at $126 \mathrm{ka}$ (high boreal summer insolation) and $122 \mathrm{ka}$ (intermediate insolation values), in comparison to $115 \mathrm{ka}$ (minimum in boreal summer insolation) (Fig. 8a). Figure 9 presents changes in surface and deep waters in the North Atlantic and Nordic Seas between these three time slices.

Northern high-latitude surface waters are warmer by 1.5 to $3{ }^{\circ} \mathrm{C}$ at $126 \mathrm{ka}$ than at $122 \mathrm{ka}$, and by around $1^{\circ} \mathrm{C}$ at $122 \mathrm{ka}$ 

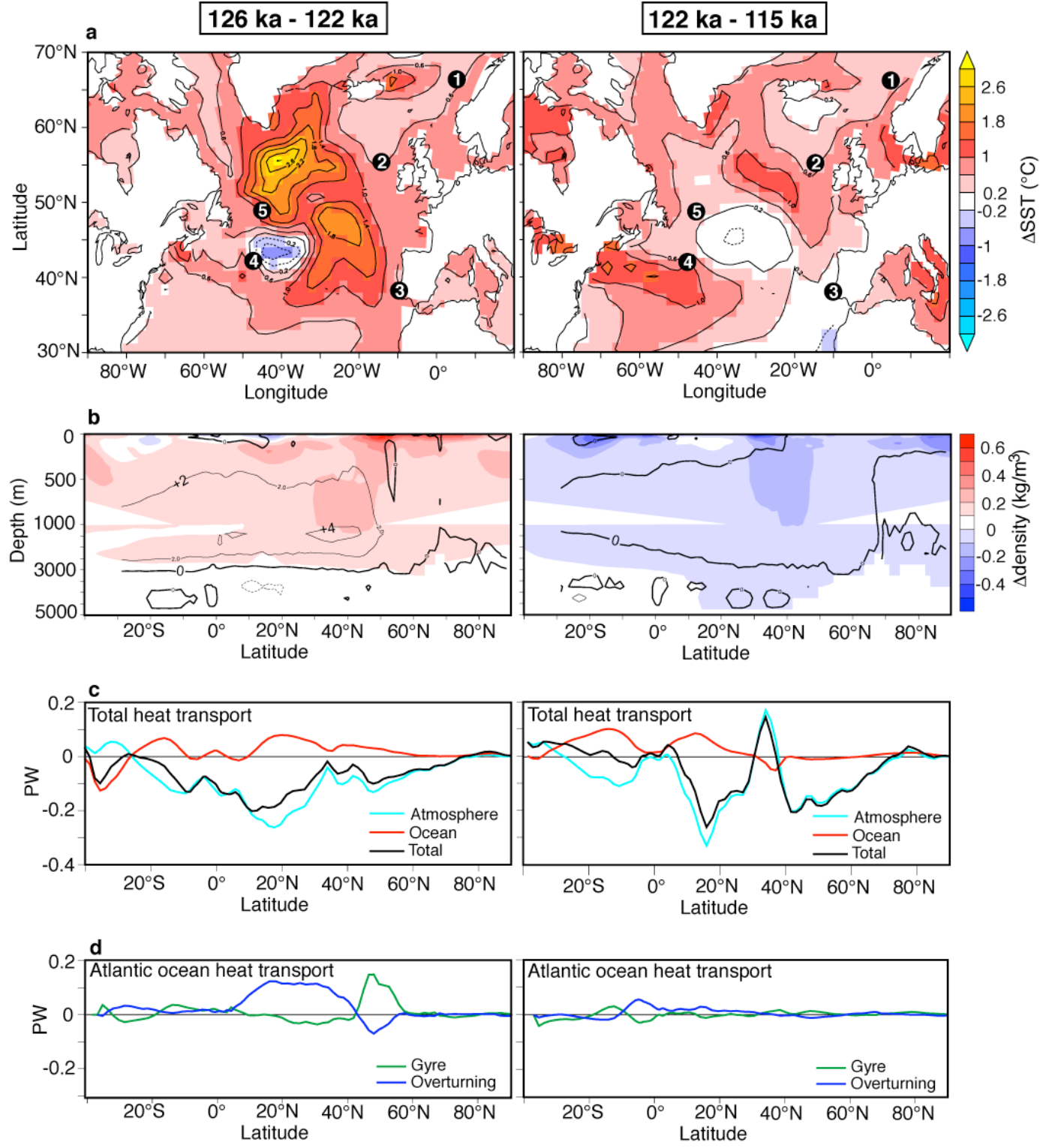

Fig. 9. Modeled climate response to insolation variations between (left panel) 126 and $122 \mathrm{ka}$, and (right panel) 122 and $115 \mathrm{ka}$. Averaged outputs over the last 100 years of the simulations are presented. We only show the statistically significant differences at the $95 \%$ level using a student t-test on the interannual variability of the last 100 years of each simulation. (a) North Atlantic map of the mean annual SST anomalies. Black circles indicate the location of the northern sediment cores considered here: (1) MD95-2010 (Risebrobakken et al., 2006), (2) ODP 980 (Oppo et al., 2006), (3) MD95-2042 (Shackleton et al., 2002), (4) CH69-K09 (Cortijo et al., 1999), and (5) EW9302-JPC2 (Rasmussen et al., 2003a). (b) Atlantic annual mean zonal density (color scale) and overturning (2 Sv contour lines, flow is clockwise around positive contour lines) anomalies. (c) Total heat transport (black line, $1 \mathrm{PW}=10^{15} \mathrm{~W}$ ), decomposed between the atmosphere (turquoise line) and the ocean (red line). (d) Atlantic Ocean heat transport decomposed into gyre (green line) and overturning (blue line) components.

than at $115 \mathrm{ka}$ (Fig. 9a). These temperature changes reflect the direct response of northern high-latitude climate to the boreal summer insolation, which gradually decreases between 126 and $115 \mathrm{ka}$ (Fig. 8a). The high obliquity at $126 \mathrm{ka}$ brings more direct solar radiation in high latitudes, thereby smoothing the temperature contrast between the tropics and the pole. As a consequence, a reduction in the total polar heat transport by the coupled ocean-atmosphere circulation is simulated between 126 and $122 \mathrm{ka}$ (Fig. 9c). It mainly results from a reduction in the atmospheric heat transport reaching up to $0.25 \mathrm{PW}\left(1 \mathrm{PW}=10^{15} \mathrm{~W}\right)$ at $20^{\circ} \mathrm{N}$ between 126 and $122 \mathrm{ka}$ (Fig. 9c). Although only slightly affected by insolation changes, the poleward ocean heat transport remains higher at $126 \mathrm{ka}$ compared to $122 \mathrm{ka}$ (Fig. 9c). This 
increase is mainly due to changes in the North Atlantic sector (up to 0.10 PW). Therefore, higher North Atlantic SSTs at $126 \mathrm{ka}$ compared to $122 \mathrm{ka}$ reflects the increase in the Atlantic poleward heat transport. Figure $9 \mathrm{~d}$ indicates that this increase in Atlantic heat transport at $126 \mathrm{ka}$ is mainly due to a stronger Atlantic overturning between the equator and $40^{\circ} \mathrm{N}$ and a stronger subpolar gyre around $50^{\circ} \mathrm{N}$ (see Born et al., 2010).

Future climate simulations with increasing atmospheric carbon dioxide concentrations show that increased North Atlantic SSTs stratify the upper water, thereby limiting the deep convection that feeds the AMOC (Gregory et al., 2005). The model however simulates here a stronger AMOC at $126 \mathrm{ka}$ than at $122 \mathrm{ka}$ (Fig. 9b), due to the sinking of denser NADW (Fig. 9b). The reasons for a stronger AMOC at $126 \mathrm{ka} \mathrm{com-}$ pared to at $122 \mathrm{ka}$ are twofold. (1) SST in late winter, when convection mostly occurs in the North Atlantic, is not different between the two periods, limiting the upper layer stabilizing effect. (2) The mechanism identified here brings the export of Arctic sea ice towards the Nordic Seas (where sea ice melts) into play. In the warmer climate at $126 \mathrm{ka}$, the production of sea ice in the Arctic is reduced, so that the export of sea ice through the Fram Strait is reduced by $0.04 \mathrm{~Sv}$ at $126 \mathrm{ka}$ compared to $122 \mathrm{ka}$. This reduced export of sea ice from the Arctic to the Atlantic Ocean tends to decrease the sea surface salinity (SSS) in the Arctic at $126 \mathrm{ka}$ compared to $122 \mathrm{ka}$. Furthermore less sea ice melts in the Nordic Seas, which increases the SSS in the Nordic Seas (not shown), sustains deep-water convection in the North Atlantic and a stronger AMOC at $126 \mathrm{ka}$ compared to $122 \mathrm{ka}$. A similar mechanism has been proposed for simulations of future climate (Hu et al., 2004; Swingedouw et al., 2007b). At the demise of the LIG, Born et al. (2010) also documented with the same climate model a weaker AMOC at $115 \mathrm{ka}$ than at $126 \mathrm{ka}$ due to this enhanced advection of Arctic sea ice into the North Atlantic. We observe here very little change in the Atlantic overturning $\left(<0.5 \mathrm{~Sv}, 1 \mathrm{~Sv}=10^{6} \mathrm{~m}^{3} \mathrm{~s}^{-1}\right)$ between $122 \mathrm{ka}$ and $115 \mathrm{ka}$ (Fig. 9b). Similarly, changes in the Atlantic oceanic heat transport (in particular in the overturning component) remain low ( $<0.05 \mathrm{PW})$ between $122 \mathrm{ka}$ and $115 \mathrm{ka}$ (Fig. 9d), while the globally decreased atmospheric heat transport in the Northern Hemisphere account for the reduction in total heat transport (Fig. 9c). Therefore, most of the AMOC reduction identified between 126 and $115 \mathrm{ka}$ during the last glacial inception (Born et al., 2010) occurs within the LIG between 126 and $122 \mathrm{ka}$. We attribute this major change in AMOC during the LIG to the increasing rate of high-latitude insolation change (Fig. 8a) that results from a rapid obliquity decrease and has a major climatic impact at high latitudes between 126 and $122 \mathrm{ka}$.

In summary, the climate model simulates a warmer climate at high northern latitudes and more intense AMOC during the early LIG (126 ka) compared to the later LIG (122 ka) in response to insolation changes. These modeling results are in contradiction with proxy data, which indicate colder surface waters at high northern latitudes and a shallower NADW cell during the early LIG compared to the late LIG. Insolation variations are hence not the sole factors regulating the climate at high northern latitudes at the beginning of the LIG.

\subsection{Additional impact of ice sheet melting on North Atlantic climate}

To evaluate the contribution of a persistent ice sheet melting on the LIG climate at high northern latitudes, we consider in addition the simulation performed at $126 \mathrm{ka}$ with interactive freshwater input ("126 ka meltwater").

When comparing the two simulations at $126 \mathrm{ka}$ ("126 ka" and "126 ka meltwater", Fig. 10), we observe colder surface waters of up to $3{ }^{\circ} \mathrm{C}$ in the North Atlantic and the Nordic Seas (up to $65^{\circ} \mathrm{N}$ ) when the meltwater is active at $126 \mathrm{ka}$ (Fig. 10a). The warming observed at higher latitudes in the Norwegian Sea (Fig. 10a) is a common feature simulated in freshwater experiments by coupled ocean-atmosphere GCM (e.g. Stouffer et al., 2006, see discussion in Sect. 4.3.3 below). In addition, the model simulates a freshening of surface waters (not shown) at high northern latitudes, which is directly linked to the freshwater input. The supply of freshwater also stratifies the upper ocean and lowers the density of NADW (Fig. 10b). The strength of the AMOC decreases by $6 \mathrm{~Sv}$ (Fig. 10b), which corresponds to a $50 \%$ reduction of the AMOC intensity at $126 \mathrm{ka}$. The weakening of the AMOC in the " 126 ka meltwater" simulation induces a strong reduction in the poleward heat transport by the Atlantic overturning (Fig. 10d), which explains the cooling simulated in North Atlantic surface waters (Fig. 10a).

The climatic patterns described above at $126 \mathrm{ka}$ correspond to classical North Atlantic climate responses computed in freshwater experiments by coupled models (e.g. Stouffer et al., 2006; Swingedouw et al., 2009). We also observe similar climate features simulated at high northern latitudes when considering the LIG climate evolution highlighted by the simulation at $126 \mathrm{ka}$ with interactive freshwater input and the one at $122 \mathrm{ka}$. Surface waters in the North Atlantic (south of $60^{\circ} \mathrm{N}$ ) are colder by up to $2^{\circ} \mathrm{C}$ (Fig. 10a) and fresher (not shown) at $126 \mathrm{ka}$ when the meltwater is active compared to at $122 \mathrm{ka}$. These characteristics are consistent with proxy-data SST and $\delta^{18} \mathrm{O}_{\mathrm{sw}}$ variations, which indicate colder and fresher conditions at high northern latitudes during the early LIG compared to the late LIG (Sect. 3.2.1). The simulated AMOC is also reduced by $4 \mathrm{~Sv}$ at $126 \mathrm{ka} \mathrm{com}-$ pared to $122 \mathrm{ka}$ (Fig. 10b). The AMOC weakening is due to the reduction of NADW production in response to the surface freshwater input at $126 \mathrm{ka}$ (Fig. 10b). The AMOC reduction simulated between $126 \mathrm{ka}$ and $122 \mathrm{ka}$ also results in a decrease in the poleward Atlantic heat transport (Fig. 10d), which explains the cooling of North Atlantic surface waters (Fig. 10a). This AMOC weakening is consistent with a shallow NADW cell indicated by North Atlantic proxy data at the beginning of the LIG (Sect. 3.2.2). The North Atlantic 

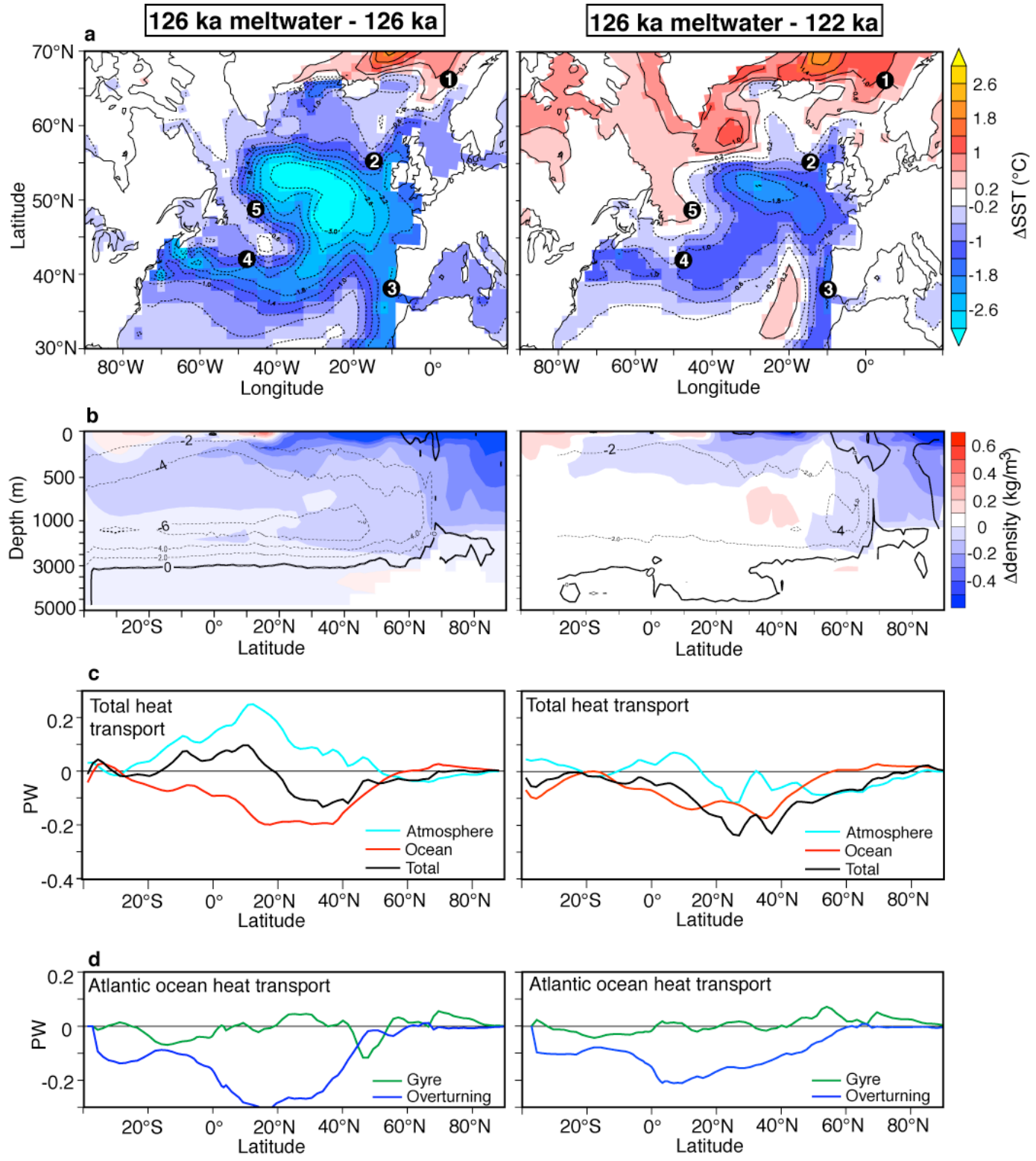

Fig. 10. Modeled climate response to the northern input of meltwater (left panel) at $126 \mathrm{ka}$ with and without meltwater, and (right panel) between $126 \mathrm{ka}$ with meltwater input and $122 \mathrm{ka}$. Averaged outputs over the last 100 years of the simulations are presented. We only show the statistically significant differences at the $95 \%$ level using a student t-test on the interannual variability of the last 100 years of each simulation. (a) North Atlantic map of the mean annual SST anomalies. Black circles indicate the location of the northern sediment cores considered here: (1) MD95-2010 (Risebrobakken et al., 2006), (2) ODP 980 (Oppo et al., 2006), (3) MD95-2042 (Shackleton et al., 2002), (4) CH69-K09 (Cortijo et al., 1999), and (5) EW9302-JPC2 (Rasmussen et al., 2003a). (b) Atlantic annual mean zonal density (color scale) and overturning (2 Sv contour lines, flow is clockwise around positive contour lines) anomalies. (c) Total heat transport (black line, $1 \mathrm{PW}=10^{15} \mathrm{~W}$ ), decomposed between the atmosphere (turquoise line) and the ocean (red line). (d) Atlantic Ocean heat transport decomposed into gyre (green line) and overturning (blue line) components.

response computed by the model at $126 \mathrm{ka}$ with interactive freshwater input compared to $122 \mathrm{ka}$ shows a better agreement with the LIG climate evolution highlighted by marine sediment cores. These results show that the persistent melting of northern ice-sheet melting at the beginning of the LIG needs to be considered in addition to insolation variations, in order to reproduce the late establishment of peak interglacial conditions indicated by proxy data at high northern latitudes. Our model-data intercomparison however presents some limitations that we discuss in the next section. 


\subsection{Discussion on the limitations of the model-data comparison}

\subsubsection{Origin of the icebergs and melting water}

In the model simulation, the meltwater input originates from the Greenland ice sheet, which is the only northern ice sheet represented in the model configuration. The freshwater flux computed is then redistributed in the Atlantic to the north of $40^{\circ} \mathrm{N}$ (Marti et al., 2010). The model simulations can hence represent the ocean and climate responses to the melting of unspecified northern ice sheets. Available data do not allow identifying the specific northern origin of ice-rafted detritus that are found in marine sediment cores from the North Atlantic and the Norwegian Sea at the beginning of the LIG (Fig. 7a). IRD are recorded at high northern latitudes at a time during the early LIG when North Atlantic benthic $\delta^{18} \mathrm{O}$ values remain low and when benthic $\delta^{18} \mathrm{O}$ variations smaller than $0.2 \%$ indicate sea level fluctuations smaller than $20 \mathrm{~m}$ (Fig. 7). This feature suggests that most glacial ice sheets have already melted away during the early LIG. A recent study indicates that ice persisted on southern Greenland throughout the LIG (Colville et al., 2011). The contribution of Greenland melting to the LIG sea level highstand has been reevaluated to $1.6 \mathrm{~m}$ to $2.2 \mathrm{~m}$ (compared to modern times) (Colville et al., 2011). This estimate agrees with the lower end inferred from model simulations (Otto-Bliesner et al., 2006). It suggests a limited contribution of the Greenland retreat to the meltwater input at the beginning of the LIG. Therefore, a significant proportion of icebergs melting in the North Atlantic during the early LIG likely originate from remnants of glacial northern ice sheets. The Eurasian Saalian ice sheet, which extended during MIS 6 further south than during any subsequent glacial episode (e.g. Svendsen et al., 2004), constitutes a very likely source for the icebergs. The influence of the melting Laurentide ice sheet can also not be excluded. Evaluating the respective contribution of northern ice sheets to the early LIG meltwater input would constitute an interesting challenge for new climate modeling studies.

\subsubsection{Magnitude of the computed freshwater flux and North Atlantic response}

The magnitude of the AMOC in the IPSL-CM4 model used here is known to be too low under preindustrial conditions compared to estimates based on observations (Swingedouw et al., 2007a). Nevertheless, the AMOC sensitivity to standard freshwater inputs (e.g. Stouffer et al., 2006) remains within the sensitivity of most coupled GCMs (Swingedouw et al., 2009).

Previous work on future climate with coupled climate ice sheet models (e.g. Ridley et al., 2005) indicates (1) the melting of the Greenland ice sheet (additional freshwater input reaching at most $0.06 \mathrm{~Sv}$ ) under warm conditions, (2) a small AMOC weakening (1-2 Sv, i.e. $<10 \%$ of the simulation without ice sheet melting) caused by the meltwater input and (3) an AMOC recovery $~ 400$ years later, when most of the additional freshwater input ceases. In our study, the freshwater input is still present at the end of the " $126 \mathrm{ka}$ meltwater" simulation (250-year long) and stabilized around $0.17 \mathrm{~Sv}$. This feature explains the large AMOC reduction at that time $(6 \mathrm{~Sv}$, i.e. $50 \%$ of the AMOC overturning at $126 \mathrm{ka}$, Fig. 3). The long-term evolution of the AMOC remains uncertain in our study. Future work should include longer simulations of the LIG climate with interactive ice sheets in order to determine the long-term impact of ice sheet melting on the AMOC.

The freshwater flux computed in response to the melting of the Greenland ice sheet under the strong insolation forcing at $126 \mathrm{ka}$ is very large $(0.17 \mathrm{~Sv})$. It explains the strong reduction in the Atlantic overturning circulation (4 Sv, i.e. $38 \%$ of the preindustrial simulation) observed between the simulations at $126 \mathrm{ka}$ with interactive freshwater flux and at $122 \mathrm{ka}$ (Fig. 10b). The large input of freshwater computed here is unrealistic for the LIG. For example, such a meltwater flux would imply the disappearance of the modern Greenland ice sheet (volume of $2.93 \times 10^{6} \mathrm{~km}^{3}$, Bamber et al., 2001) in around 550 years. This value contradicts the reduction (not disappearance) of the Greenland ice sheet reconstructed for the LIG (e.g. Koerner, 1989; North Greenland Ice Core Project members, 2004; Otto-Bliesner et al., 2006; Willerslev et al., 2007). The simulation performed at $126 \mathrm{ka}$ with the interactive freshwater flux should hence be considered as a maximum perturbation of the North Atlantic climate during the LIG induced by an extreme input of meltwater. Melting with such a magnitude could have only occurred on a very limited time scale. The climate conditions computed in the " 126 ka meltwater" simulation are probably representative of climate conditions at the very beginning of the LIG (e.g. 130-129 ka), when intense iceberg discharge took place at high northern latitudes. The "real" ocean and climate responses to insolation variations and meltwater input during the early LIG are likely to be intermediate between the two simulations at $126 \mathrm{ka}$, with and without the interactive freshwater input.

Using an ensemble of sensitivity experiments with a model of intermediate complexity, Bakker et al. (2011) investigated the range of Greenland melting rate at the beginning of the LIG. They indicate a possible range between 0.052 and $0.13 \mathrm{~Sv}$ of the meltwater flux that resulted in decreased deep convection and reduced air temperatures over the North Atlantic and the Labrador Sea (Bakker et al., 2011). This study confirms the extremely high freshwater flux computed in our study. It also shows with "more realistic" freshwater values the similar impact of northern ice sheet melting on North Atlantic climate that we report at the beginning of the LIG. In addition, relatively stable North Atlantic benthic $\delta^{18} \mathrm{O}$ data during the early LIG (Fig. 8c) suggest sea level fluctuations smaller than $20 \mathrm{~m}$. Assuming a sea level rise of maximum 
$20 \mathrm{~m}$ during the 3-4 ka of persistent IRD deposition at the beginning of the LIG implies a mean freshwater flux of 0.06 to $0.08 \mathrm{~Sv}$ (that was probably irregular and higher at $130 \mathrm{ka}$ than $126 \mathrm{ka})$. Although highly uncertain, these values fall within the range of meltwater flux inferred by Bakker et al. (2011).

Nevertheless, all these elements highlight the critical need in the near future to couple ice sheet and climate models in order to improve the computation of freshwater fluxes and realistically estimate their impact on North Atlantic climate.

\subsubsection{Climatic response in the Norwegian Sea}

Model results and proxy data disagree on the climatic response during the early LIG in the Norwegian Sea. Marine sediment cores record a late thermal optimum during the LIG, i.e. colder SST during the early LIG than the late LIG. The delay in the establishment of peak interglacial warmth indicated by marine records during the LIG appears to be a robust feature of the LIG climate evolution in the entire Norwegian Sea (Fronval and Jansen, 1997; Fronval et al., 1998; Rasmussen et al., 2003b; Bauch and Erlenkeuser, 2008; Bauch et al., 2011; Van Nieuwenhove et al., 2011). Although uncertainties on the chronologies of sediment cores from the Norwegian Sea remain relatively high for the LIG, independent age models of Norwegian Sea cores based on tephra layers support the late thermal optimum in the Nordic Seas (Wastegaard and Rasmussen, 2001; Rasmussen et al., 2003b).

In contrast, the IPSL-CM4 model simulates a warming of several degrees in the Norwegian Sea between the early LIG ("126 ka meltwater" simulation) and late LIG ("122 ka" simulation) (Fig. 10a). Given the large amount of freshwater redistributed at high northern latitudes in the model (see Sect. 4.3.2), the magnitude of this warming is probably overestimated in comparison to a potential "real" surface-water warming signal in the Norwegian Sea. This warming pattern, which is observed in response to freshwater input under different climate conditions, is a common feature of freshwater experiments in this model (Swingedouw et al., 2009). It is due to the adjustment of atmospheric dynamics in response to the initial global cooling. The changes in atmospheric dynamics increases the surface currents and the contribution of the gyre to the Atlantic heat transport north of $60^{\circ} \mathrm{N}$ (Fig. 10d). These two effects (wind and ocean) reduce the sea ice cover along the eastern coast of Greenland, which leads to a warming in the Norwegian Sea (see Swingedouw et al., 2009 for further details). This warming pattern is not only a characteristic of the IPSL-CM4 model. Most atmosphereocean coupled models simulate this warming signal in the Nordic Seas in response to freshwater input (e.g. Stouffer et al., 2006; Saenko et al., 2007). Further studies on the reasons for such adjustments of the atmospheric circulation appear to be necessary to reconcile the LIG climate history seen by model simulations and proxy data in the Norwegian Sea.

\subsubsection{Alternative mechanisms to the early LIG climatic pattern?}

Although the presence of IRD in North Atlantic and Norwegian Sea cores (Fig. 7a) strongly argues in favour of ice sheet melting during the early LIG, other modelling studies exhibit a similar cold North Atlantic climate (Felis et al., 2004; Kaspar and Cubasch, 2007) or weakened AMOC (Khodri et al., 2003; Gröger et al., 2007) during the LIG insolation peak without meltwater forcing. Felis et al. (2004) and Kaspar et al. (2007) simulate with the same GCM colder air temperatures (up to $2^{\circ} \mathrm{C}$ ) above the Labrador Sea, the southern Nordic Seas and the North Atlantic (north of $40^{\circ} \mathrm{N}$ ) during the early LIG (at $124 \mathrm{ka}$ and $125 \mathrm{ka}$ respectively) compared to preindustrial times. They simulate by contrast a warming over Europe, North America and the tropical North Atlantic (Felis et al., 2004; Kaspar and Cubasch, 2007). These authors attribute this LIG temperature pattern to a high positive index of the North Atlantic Oscillation (NAO) (Felis et al., 2004). The increased pressure difference between the North Atlantic high and Icelandic low results from a reduced poleto-equator temperature gradient and weakened Hadley cell in response to the reduced boreal winter insolation in the tropics (Felis et al., 2004). In our study, we observe no such temperature pattern, neither between 126 and $122 \mathrm{ka}$ (Fig. 9a) nor between $126 \mathrm{ka}$ and preindustrial times (not shown). The discrepancy between these two GMCs certainly calls for further detailed investigations of the LIG climate with other models. These authors however did not discuss the change in ocean circulation (Felis et al., 2004; Kaspar and Cubasch, 2007).

Few modelling studies investigated the climate evolution throughout the LIG (e.g. Crucifix and Loutre, 2002; Khodri et al., 2003; Calov et al., 2005; Gröger et al., 2007). At the beginning of the LIG, they simulate an enhanced (this study, Crucifix and Loutre, 2002; Calov et al., 2005) or weakened AMOC (Khodri et al., 2003; Gröger et al., 2007) in response to insolation variations. This feature highlights the difference in overturning sensitivity in the models during the LIG, as already outlined for future climate simulations (Schmittner et al., 2005; Schneider et al., 2007). In particular, two transient studies indicate a decrease in AMOC during the early LIG (e.g. $125 \mathrm{ka}$ ) compared to the late LIG (e.g. $120 \mathrm{ka}$ ) without meltwater forcing (Khodri et al., 2003; Gröger et al., 2007). The mechanisms involved differ. The slight AMOC weakening (by $1 \mathrm{~Sv}$, i.e. $~ 5 \%$ ) simulated by Khodri et al. (2003) results from higher freshwater input in the Arctic $(+0.01 \mathrm{~Sv})$ that decreases the SSS in the Arctic and hence the Nordic Seas, thereby limiting the deep convection. The AMOC weakening (by 3 Sv, i.e. up to $20 \%$ ) simulated by Gröger et al. (2007) results from (1) warmer North Atlantic surface waters that stratify the upper water column and (2) a $0.027 \mathrm{~Sv}$ increase in freshwater input in the Arctic/North Atlantic drainage basin. In their model, no decrease in sea ice transport through the Fram Strait is reported, which differs from our study. The processes related to the export of 
Arctic sea ice that we identify here (Sect. 4.1) are not specific to the IPSL-CM4 model. In future climate projections, $\mathrm{Hu}$ et al. (2004) showed that similar sea ice processes contributed to the future evolution of the AMOC simulated with the Parallel Climate Model. In addition, the model used by Gröger et al. (2007) comprises flux corrections for freshwater and wind stress, which can largely affect its sensitivity to different climatic conditions and explain the difference in sensitivity between the two models. Finally, both transient studies exhibit higher North Atlantic SST and SSS during the early LIG compared to the late LIG (Khodri et al., 2003; Gröger et al., 2007). This pattern is in contradiction with our compilation of proxy data (Fig. 7).

The evolution of the Arctic freshwater budget and its impact on North Atlantic climate during the LIG remain unclear. Past changes in precipitation are difficult to estimate from proxy data. Qualitative estimates suggest wetter conditions in most Arctic sectors during the LIG compared to the Holocene (Cape Last Interglacial Project members, 2006; Miller et al., 2010). The response of the Arctic freshwater budget to the sole insolation forcing differs in modelling studies. Whereas it is slightly reduced at $126 \mathrm{ka}$ compared to $122 \mathrm{ka}$ in our study (not shown), it is slightly increased in other LIG simulations due to increased Arctic precipitation during the early LIG (Khodri et al., 2003; Gröger et al., 2007). Depending on the simulations, Arctic freshwater variations can have an impact on the AMOC (Khodri et al., 2003), be overprinted by the warming of surface waters (Gröger et al., 2007) or by changes in Arctic sea ice export to the Nordic Seas (our study, Sect. 4.1). Therefore, the impact of insolation changes on the AMOC remains under debate. Mechanisms with opposite effect on the AMOC come into play. Depending on their relative magnitude in the models, these mechanisms can lead to different AMOC responses, as already illustrated in future climate projections (Gregory et al., 2005).

In summary, our simulations are so far the only ones that reproduce both the cooling/freshening in high northern latitudes and AMOC weakening documented during the early LIG by proxy data. This characteristic tends to support our assumption of persistent ice sheet melting at the beginning of the LIG. However, other models are able to simulate part of the LIG climatic pattern (North Atlantic cooling or AMOC reduction) identified here without freshwater input. The variety of mechanisms involved (e.g. high NAO index, Arctic freshwater budget, temperature effect on density) leaves the question open to alternative explanations. Further investigation with different models is clearly required to disentangle the climatic forcing and mechanisms regulating the LIG climate.

\section{Conclusions}

Our compilation of proxy data for the LIG documents a delay in the establishment of peak interglacial conditions at high northern latitudes compared to high southern latitudes. We observe a persistent northern freshwater supply at the beginning of the LIG. It is associated with (1) relatively low salinity and temperature values in surface waters from the North Atlantic, Labrador and Norwegian Seas, and (2) a relatively weak ventilation of North Atlantic deep waters during the early LIG (129-125 ka) compared to the late LIG. These results indicate that the late thermal optimum documented in the Norwegian Sea (Bauch and Erlenkeuser, 2008; Bauch et al., 2011; Van Nieuwenhove et al., 2011) also takes place in the Labrador Sea and high-latitude North Atlantic regions. It also has its counterpart at depth, with a shallower North Atlantic deep-water cell during the early LIG (Hodell et al., 2009). At the beginning of the LIG, oceanic conditions at high northern latitudes are hence intermediate between glacial and full interglacial conditions.

The comparison with model results indicates that the delay in peak interglacial conditions at high northern latitudes cannot be a direct response to insolation variations. In response to the sole insolation forcing, North Atlantic surface waters are warmer and more saline during the early LIG (126 ka) compared to the late LIG (122 ka). In that case, the Atlantic thermohaline circulation is also stronger at $126 \mathrm{ka}$ than at $122 \mathrm{ka}$. The modelled climate response to insolation variations is in contradiction to the LIG climate evolution indicated by proxy data. The model better reproduces the LIG climate history when the melting of northern ice sheets is considered during the early LIG (126 ka). North Atlantic surface waters are indeed colder and fresher, and the Atlantic meridional overturning weaker, at $126 \mathrm{ka}$ with interactive freshwater flux compared to $122 \mathrm{ka}$. Insolation variations and persistent northern meltwater input hence need to be both considered in order to reproduce the late establishment of peak interglacial conditions during the LIG. This result emphasizes the sensitivity of North Atlantic climate to the melting of northern ice sheets in a warm climate and the necessity to consider ice-sheet melting in the simulations of warm climates.

Our model-data comparison also reveals the limits of our set of simulations performed with one ocean-atmosphere coupled model to reproduce the LIG climate evolution. The freshwater flux computed in this study is extremely high and cannot represent the real climate of the early LIG. In addition, other models can reproduce part of the climatic pattern (North Atlantic cooling or AMOC reduction) that we identify here at the beginning of the LIG without freshwater input. They bring a variety of processes into play (e.g. Arctic freshwater budget, NAO, temperature/salinity effect on density). These results highlight the critical need in the near future to (1) develop ice sheet-climate coupled models to improve the computation of freshwater fluxes and realistically simulate 
the magnitude of freshwater input and climatic responses, (2) perform transient experiments lasting few thousand years to investigate the long-term impact of ice sheet melting on the AMOC and North Atlantic climate, and (3) compare simulations performed with a variety of models to evaluate the climatic forcing and mechanisms that are most likely to influence the LIG climate.

Acknowledgements. We thank Gulay Isguder (LSCE) and Fabien Dewilde (LSCE) for increasing the resolution of respectively the SST and benthic isotopic records from core MD02-2488. Discussions with Dominique Raynaud and Didier Paillard helped to improve an early version of the manuscript. We gratefully acknowledge the constructive comments of three anonymous referees and the editor (M. Siddall). We also thank the crew of the research vessel Marion-Dufresne and the French Paul Emile Victor Institute (IPEV) for collecting most of the cores studied here. Funding of the cruises has been facilitated by IMAGES scientific collaborations. Part of this study has been performed within the framework of the French National Research Agency ANR PICC project. The research leading to these results has received funding from the European Union's Seventh Framework programme (FP7/2007-2013) under grant agreement no. 243908, "Past4Future. Climate change - Learning from the past climate". This is LSCE publication no. 4754.

Edited by: M. Siddall

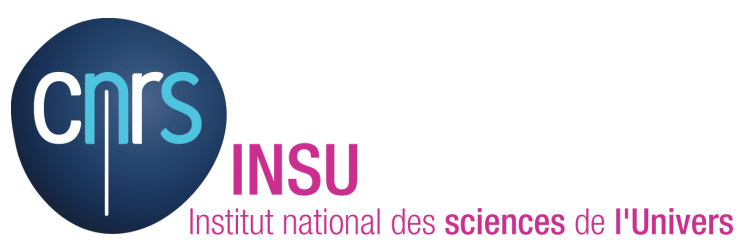

The publication of this article is financed by CNRS-INSU.

\section{References}

Adkins, J. F., Boyle, E. A., Keigwin, L. D., and Cortijo, E.: Variability of the North Atlantic thermohaline circulation during the last interglacial period, Nature, 390, 154-156, 1997.

Andersson, C., Pausata, F. S. R., Jansen, E., Risebrobakken, B., and Telford, R. J.: Holocene trends in the foraminifer record from the Norwegian Sea and the North Atlantic Ocean, Clim. Past, 6, 179-193, doi:10.5194/cp-6-179-2010, 2010.

Bakker, P., Van Meerbeeck, C. J., and Renssen, H.: Sensitivity of the North Atlantic climate to Greenland Ice Sheet melting during the Last Interglacial, Clim. Past Discuss., 7, 2763-2801, doi:10.5194/cpd-7-2763-2011, 2011.

Bamber, J. L., Layberry, R. L., and Gogineni, S. P.: A new ice thickness and bed data set for the Greenland ice sheet 1. Measurement, data reduction, and errors, J. Geophys. Res., 106, 33773-33780, doi:10.1029/2001jd900054, 2001.

Bard, E., Arnold, M., and Duplessy, J. C.: Reconciling the sea level record of the last deglaciation with the $\mathrm{d} 18 \mathrm{O}$ spectra from deep sea cores, in: Radiocarbon dating: recent applications and fu- ture potential, edited by: Lowe, J. J., Quaternary Proceedings, Quaternary Research Association, Cambridge, 67-73, 1991.

Bauch, H. A. and Erlenkeuser, H.: A "critical" climatic evaluation of last interglacial (MIS 5e) records from the Norwegian Sea, Polar Res., 27, 135-151, 2008.

Bauch, H. A. and Kandiano, E. S.: Evidence for early warming and cooling in North Atlantic surface waters during the last interglacial, Paleoceanography, 22, PA1201, doi:10.1029/2005pa001252, 2007.

Bauch, H. A., Kandiano, E. S., Helmke, J., Andersen, N., RosellMele, A., and Erlenkeuser, H.: Climatic bisection of the last interglacial warm period in the Polar North Atlantic, Quaternary Sci. Rev., 30, 1813-1818, doi:10.1016/j.quascirev.2011.05.012, 2011.

Berger, A. and Loutre, M. F.: Insolation values for the climate of the last 10 million years, Quaternary Sci. Rev., 10, 297-317, 1991.

Berger, A. L.: Long-Term Variations of Daily Insolation and Quaternary Climatic Changes, J. Atmos. Sci., 35, 2362-2367, 1978.

Birks, C. J. A. and Koç, N.: A high-resolution diatom record of lateQuaternary sea-surface temperatures and oceanographic conditions from the eastern Norwegian Sea, Boreas, 31, 323-344, doi:10.1111/j.1502-3885.2002.tb01077.x, 2002.

Blanchon, P., Eisenhauer, A., Fietzke, J., and Liebetrau, V.: Rapid sea-level rise and reef back-stepping at the close of the last interglacial highstand, Nature, 458, 881-884, 2009.

Blunier, T. and Brook, E. J.: Timing of millenial-scale climate change in Antarctica and Greenland during the Last Glacial Period, Science, 291, 109-112, 2001.

Bond, G. C., Broecker, W., Johnsen, S., McManus, J., Labeyrie, L., Jouzel, J., and Bonani, G.: Correlations between climate records from the North Atlantic sediments and Greenland Ice, Nature, 365, 143-147, 1993.

Born, A., Nisancioglu, K., and Braconnot, P.: Sea ice induced changes in ocean circulation during the Eemian, Clim. Dynam., 35, 1361-1371, doi:10.1007/s00382-009-0709-2, 2010.

Braconnot, P., Marzin, C., Grégoire, L., Mosquet, E., and Marti, O.: Monsoon response to changes in Earth's orbital parameters: comparisons between simulations of the Eemian and of the Holocene, Clim. Past, 4, 281-294, doi:10.5194/cp-4-281-2008, 2008.

Calov, R., Ganopolski, A., Petoukhov, V., Claussen, M., Brovkin, V., and Kubatski, C.: Transient simulation of the last glacial inception, Part II: sensitivity and feedback analysis, Clim. Dynam., 24, 563-576, 2005.

Calvo, E., Grimalt, J., and Jansen, E.: High resolution U37K sea surface temperature reconstruction in the Norwegian Sea during the Holocene, Quaternary Science Reviews, 21, 1385-1394, doi:10.1016/S0277-3791(01)00096-8, 2002.

Calvo, E., Pelejero, C., de Deckker, P., and Logan, G. A.: Antarctic deglacial pattern in a $30 \mathrm{kyr}$ record of sea surface temperature offshore South Australia, Geophys. Res. Lett., 34, L13707, doi:10.1029/2007GL029937, 2007.

Came, R. E., Oppo, D. W., and McManus, J. F.: Amplitude and timing of temperature and salinity variability in the subpolar North Atlantic over the past 10 k.y, Geology, 35, 315-318, doi:10.1130/g23455a.1, 2007.

Cape Last Interglacial Project members: Last Interglacial Arctic warmth confirms polar amplification of climate change, Quaternary Sci. Rev., 25, 1383-1400, 2006. 
Capron, E., Landais, A., Lemieux-Dudon, B., Schilt, A., MassonDelmotte, V., Buiron, D., Chappellaz, J., Dahl-Jensen, D., Johnsen, S., Leuenberger, M., Loulergue, L., and Oerter, H.: Synchronising EDML and NorthGRIP ice cores using $\delta^{18} \mathrm{O}$ of atmospheric oxygen $\left(\delta^{18} \mathrm{O}_{\mathrm{atm}}\right)$ and $\mathrm{CH}_{4}$ measurements over MIS5 (80-123 kyr), Quaternary Sci. Rev., 29, 222-234, doi:10.1016/j.quascirev.2009.07.014, 2010.

Carlson, A. E.: Why there was not a Younger Dryas-like event during the Penultimate Deglaciation, Quaternary Sci. Rev., 27, 882$887,2008$.

Chapman, M. R. and Shackleton, N. J.: Millennial-scale fluctuations in North Atlantic heat flux during the last 150,000 years, Earth Planet. Sci. Lett., 159, 57-70, 1998.

Chapman, M. R., Shackleton, N. J., and Duplessy, J.-C.: Sea surface temperature variability during the last glacial-interglacial cycle: assessing the magnitude and pattern of climate change in the North Atlantic, Palaeogeogr. Palaeocli., 157, 1-25, doi:10.1016/S0031-0182(99)00168-6, 2000.

Chappellaz, J., Bluniert, T., Raynaud, D., Barnola, J. M., Schwander, J., and Stauffert, B.: Synchronous changes in atmospheric $\mathrm{CH}_{4}$ and Greenland climate between 40 and $8 \mathrm{kyr} \mathrm{BP}$, Nature, 366, 443-445, doi:10.1038/366443a0, 1993.

Clark, P. U. and Huybers, P.: Global change: Interglacial and future sea level, Nature, 462, 856-857, doi:10.1038/462856a, 2009.

Colville, E. J., Carlson, A. E., Beard, B. L., Hatfield, R. G., Stoner, J. S., Reyes, A. V., and Ullman, D. J.: Sr-Nd-Pb Isotope Evidence for Ice-Sheet Presence on Southern Greenland During the Last Interglacial, Science, 333, 620-623, doi:10.1126/science.1204673, 2011.

Cortijo, E., Duplessy, J. C., Labeyrie, L., Leclaire, H., Duprat, J., and van Weering, T. C. E.: Eemian cooling in the Norwegian Sea and North Atlantic ocean preceding continental ice-sheet growth, Nature, 372, 446-449, 1994.

Cortijo, E., Lehman, S., Keigwin, L., Chapman, M., Paillard, D., and Labeyrie, L.: Changes in meridional temperature and salinity gradients in the North Atlantic Ocean $\left(30-72^{\circ} \mathrm{N}\right)$ during the last interglacial period, Paleoceanography, 14, 23-33, 1999.

Crucifix, M. and Loutre, F.: Transient simulations over the last interglacial period (126-115 kyr BP): feedback and forcing analysis, Clim. Dynam., 19, 417-433, doi:10.1007/s00382-002-0234z, 2002.

Cutler, K. B., Edwards, R. L., Taylor, F. W., Cheng, H., Adkins, J., Gallups, C. D., Cutler, P. M., Burr, G. S., and Bloom, A. L.: Rapid sea-level fall and deep-ocean temperature change since the last interglacial period, Earth Planet. Sc. Lett., 206, 253-271, 2003.

Denton, G. H., Anderson, R. F., Toggweiler, J. R., Edwards, R. L., Schaefer, J. M., and Putnam, A. E.: The Last Glacial Termination, Science, 328, 1652-1656, doi:10.1126/science.1184119, 2010

Desprat, S., Sanchez Goni, M. F., Naughton, F., Turon, J.-L., Duprat, J., Malaizé, B., Cortijo, E., and Peypouquet, J.-P.: Climate variability of the last five isotopic interglacials: direct land-sea-ice correlation from the multiproxy analysis of NorthWestern Iberian margin deep-sea cores, in: The Climate of Past Interglacials, edited by: Sirocko, F., Claussen, M., Sanchez Goni, M. F., and Litt, T., Developments in Quaternary Science, Vol. 7, Elsevier, Amsterdam, 375-386, 2007.

Dokken, T. and Jansen, E.: Rapid changes in the mechanism of ocean convection during the last glacial period, Nature, 401, 458-461, 1999.

Duplessy, J. C., Labeyrie, L., Juillet-Leclerc, A., Maitre, F., Duprat, J., and Sarnthein, M.: Surface salinity reconstruction of the North Atlantic Ocean during the last glacial maximum, Oceanol. Acta, 14, 311-324, 1991.

EPICA Community members: Eight glacial cycles from an Antarctic ice core, Nature, 429, 623-628, 2004.

EPICA Community members: One-to-one coupling of glacial climate variability in Greenland and Antarctica, Nature, 444, 195 198, 2006.

Felis, T., Lohmann, G., Kuhnert, H., Lorenz, S. J., Scholz, D., Pätzold, J., Al-Rousan, S. A., and Al-Moghrabi, S. M.: Increased seasonality in Middle East temperatures during the last interglacial period, Nature, 429, 164-168, doi:10.1038/nature02546, 2004.

Fichefet, T. and Maqueda, M. A. M.: Sensitivity of a global sea ice model to the treatment of ice thermodynamics and dynamics, J. Geophys. Res., 102, 12609-12646, doi:10.1029/97jc00480, 1997.

Flückiger, J., Blunier, T., Stauffer, B., Chappellaz, J., Spahni, R., Kawamura, K., Schwander, J., Stocker, T., and Dahl-Jensen, D.: $\mathrm{N}_{2} \mathrm{O}$ and $\mathrm{CH}_{4}$ variations during the last glacial epoch: insight into global processes, Global Biogeochem. Cy., 18, GB1020, doi:10.1029/2003gb002122, 2004.

Fronval, T. and Jansen, E.: Eemian and Early Weichselian (140$60 \mathrm{ka}$ ) Paleoceanography and Paleoclimate in the Nordic Seas With Comparisons to Holocene Conditions, Paleoceanography, 12, 443-462, doi:10.1029/97pa00322, 1997.

Fronval, T., Jansen, E., Haflidason, H., and Sejrup, H. P.: Variability in surface and deep water conditions in the Nordic Seas during the last interglacial period, Quaternary Sci. Rev., 17, 963-985, 1998.

Ganopolski, A. and Roche, D. M.: On the nature of lead-lag relationships during glacial-interglacial climate transitions, Quaternary Sci. Rev., 28, 3361-3378, doi:10.1016/j.quascirev.2009.09.019, 2009.

Ganssen, G. M. and Kroon, D.: The isotopic signature of planktonic foraminifera from NE Atlantic surface sediments: implications for the reconstruction of past oceanic conditions, J. Geol. Soc., 157, 693-699, doi:10.1144/jgs.157.3.693, 2000.

Govin, A., Michel, E., Labeyrie, L., Waelbroeck, C., Dewilde, F., and Jansen, E.: Evidence for northward expansion of Antarctic Bottom Water mass in the Southern Ocean during the last glacial inception, Paleoceanography, 24, PA1202, doi:10.1029/2008PA001603, 2009.

Gregory, J. M., Stouffer, K. W. D. R. J., Weaver, A. J., Driesschaert, E., Eby, M., Fichefet, T., Hasumi, H., Hu, A., Jungclaus, J. H., Kamenkovich, I. V., Levermann, A., Montoya, M., Murakami, S., Nawrath, S., Oka, A., Sokolov, A. P., and Thorpe, R. B.: A model intercomparison of changes in the Atlantic thermohaline circulation in response to increasing atmospheric $\mathrm{CO}_{2}$ concentration, Geophys. Res. Lett., 32, L12703, doi:10.1029/2005GL023209, 2005.

Gröger, M., Maier-Reimer, E., Mikolajewicz, U., Schurgers, G., Vizcaíno, M., and Winguth, A.: Changes in the hydrological cycle, ocean circulation, and carbon/nutrient cycling during the last interglacial and glacial transition, Paleoceanography, 22, PA4205, doi:10.1029/2006pa001375, 2007. 
Hald, M., Andersson, C., Ebbesen, H., Jansen, E., KlitgaardKristensen, D., Risebrobakken, B., Salomonsen, G. R., Sarnthein, M., Sejrup, H. P., and Telford, R. J.: Variations in temperature and extent of Atlantic Water in the northern North Atlantic during the Holocene, Quaternary Sci. Rev., 26, 3423-3440, doi:10.1016/j.quascirev.2007.10.005, 2007.

Hodell, D. A., Minth, E. K., Curtis, J. H., McCave, I. N., Hall, I. R., Channell, J. E. T., and Xuan, C.: Surface and deepwater hydrography on Gardar Drift (Iceland Basin) during the last interglacial period, Earth Planet. Sc. Lett., 288, 10-19, doi:10.1016/j.epsl.2009.08.040, 2009.

Hourdin, F., Musat, I., Bony, S., Braconnot, P., Codron, F., Dufresne, J.-L., Fairhead, L., Filiberti, M.-A., Friedlingstein, P., Grandpeix, J.-Y., Krinner, G., LeVan, P., Li, Z.-X., and Lott, F.: The LMDZ4 general circulation model: climate performance and sensitivity to parametrized physics with emphasis on tropical convection, Clim. Dynam., 27, 787-813, doi:10.1007/s00382006-0158-0, 2006.

$\mathrm{Hu}$, A., Meehl, G. A., Washington, W. M., and Dai, A.: Response of the Atlantic Thermohaline Circulation to Increased Atmospheric $\mathrm{CO}_{2}$ in a Coupled Model, J. Climate, 17, 4267-4279, doi:10.1175/jcli3208.1, 2004.

Huber, C., Leuenberger, M., Spahni, R., Fluckiger, J., Schwander, J., Stocker, T. F., Johnsen, S., Landais, A., and Jouzel, J.: Isotope calibrated Greenland temperature record over Marine Isotope Stage 3 and its relation to $\mathrm{CH}_{4}$, Earth Planet. Sc. Lett., 243, 504-519, 2006.

Jansen, E., Overpeck, J. T., Briffa, K. R., Duplessy, J. C., Joos, F., Masson-Delmotte, V., Olago, D., Otto-Bliesner, B., Peltier, W. R., Rahmstorf, S., Ramesh, R., Raynaud, D., Rind, D., Solomina, O., Villalba, R., and Zhang, D.: Palaeoclimate, in: Climate Change 2007: The Physical Science Basis, Contribution of Working Group I to the Four Assessment Report of the Intergovernmental Panel on Climate Change, edited by: Solomon, S., Qin, D., Manning, M., Chen, Z., Marquis, M., Averyt, K. B., Tignor, M., and Miller, H. L., Cambridge University Press, Cambridge, UK and New York, NY, USA, 2007.

Jennings, A. E., Tedesco, K. A., Andrews, J. T., and Kirby, M. E.: Shelf erosion and glacial ice proximity in the Labrador Sea during and after Heinrich events (H-3 or 4 to $\mathrm{H}-0)$ as shown by foraminifera, in: Late Quaternary Paleoceanography of the North Atlantic Margins edited by: Andrews, J. T., Austin, W. E. N., Bergsten, H., and Jennings, A. E., 1, Geological Society, London, 29-49, 1996.

Jouzel, J., Masson-Delmotte, V., Cattani, O., Dreyfus, G., Falourd, S., Hoffmann, G., Minster, B., Nouet, J., Barnola, J. M., Chappellaz, J., Fischer, H., Gallet, J. C., Johnsen, S., Leuenberger, M., Loulergue, L., Luethi, D., Oerter, H., Parrenin, F., Raisbeck, G., Raynaud, D., Schilt, A., Schwander, J., Selmo, E., Souchez, R., Spahni, R., Stauffer, B., Steffensen, J. P., Stenni, B., Stocker, T. F., Tison, J. L., Werner, M., and Wolff, E. W.: Orbital and Millennial Antarctic Climate Variability over the Past 800,000 Years, Science, 317, 793-796, doi:10.1126/science.1141038, 2007.

Kandiano, E. S., Bauch, H. A., and Müller, A.: Sea Surface temperature variability in the North Atlantic during the last two glacialinterglacial cycles: comparison of faunal, oxygen isotopic, and $\mathrm{Mg} / \mathrm{Ca}$-derived records, Palaeogeogr. Palaeocl., 204, 145-164, 2004.

Kanzow, T., Cunningham, S. A., Johns, W. E., Hirschi, J. J. M.,
Marotzke, J., Baringer, M. O., Meinen, C. S., Chidichimo, M. P., Atkinson, C., Beal, L. M., Bryden, H. L., and Collins, J.: Seasonal Variability of the Atlantic Meridional Overturning Circulation at $26.5^{\circ} \mathrm{N}$, J. Climate, 23, 5678-5698, doi:10.1175/2010jcli3389.1, 2010.

Kaspar, F. and Cubasch, U.: 33. Simulations of the Eemian interglacial and the subsequent glacial inception with a coupled ocean-atmosphere general circulation model, in: Developments in Quaternary Sciences, edited by: Sirocko, F., Claussen, M., Sánchez Goñi, M. F., and Litt, T., Elsevier, 499-515, 2007.

Keigwin, L. D., Curry, W. B., Lehman, S. J., and Johnsen, S.: The role of the deep ocean in North Atlantic climate change between 70 and 130 kyr ago, Nature, 371, 323-326, 1994.

Kelly, M. J., Edwards, R. L., Cheng, H., Yuan, D., Cai, Y., Zhang, M., Lin, Y., and An, Z.: High resolution characterization of the Asian Monsoon between 146,000 and 99,000 years B.P. from Dongge Cave, China and global correlation of events surrounding Termination II, Palaeogeogr. Palaeocl., 236, 20-38, doi:10.1016/j.palaeo.2005.11.042, 2006.

Khodri, M., Ramstein, G., Paillard, D., Duplessy, J. C., Kageyama, M., and Ganopolski, A.: Modelling the climate evolution from the last interglacial to the start of the last glaciation: The role of Arctic Ocean freshwater budget, Geophys. Res. Lett., 30, 1606, doi:10.1029/2003g1017108, 2003.

Koç Karpuz, N., and Jansen, E.: A High-Resolution Diatom Record of the Last Deglaciation from the SE Norwegian Sea: Documentation of Rapid Climatic Changes, Paleoceanography, 7, 499520, doi:10.1029/92pa01651, 1992.

Koerner, R. M.: Ice Core Evidence for Extensive Melting of the Greenland Ice Sheet in the Last Interglacial, Science, 244, 964 968, doi:10.1126/science.244.4907.964, 1989.

Kopp, R. E., Simons, F. J., Mitrovica, J. X., Maloof, A. C., and Oppenheimer, M.: Probabilistic assessment of sea level during the last interglacial stage, Nature, 462, 863-867, doi:10.1038/nature08686, 2009.

Krinner, G., Viovy, N., de Noblet-Ducoudré, N., Ogée, J., Polcher, J., Friedlingstein, P., Ciais, P., Sitch, S., and Prentice, I. C.: A dynamic global vegetation model for studies of the coupled atmosphere-biosphere system, Global Biogeochem. Cy., 19, GB1015, doi:10.1029/2003gb002199, 2005.

Kucera, M., Weinelt, M., Kiefer, T., Pflaumann, U., Hayes, A., Chen, M. T., Mix, A. C., Barrows, T. T., Cortijo, E., Duprat, J., Juggins, S., and Waelbroeck, C.: Reconstruction of sea-surface temperatures from assemblages of planktonic foraminifera: multi-technique approach based on geographically constrained calibration data sets and its application to glacial Atlantic and Pacific Oceans, Quaternary Sci. Rev., 24, 951-998, 2005.

Kukla, G., McManus, J. F., Rousseau, D. D., and Chuine, I.: How long and how stable was the last interglacial?, Quaternary Sci. Rev., 16, 605-612, 1997.

Kukla, G. J., Bender, M. L., de Beaulieu, J. L., Bond, G. C., Broecker, W., Cleveringa, P., Gavin, J. E., Herbert, T. D., Imbrie, J., Jouzel, J., Keigwin, L. D., Knudsen, K. L., McManus, J. F., Merkt, J., Muhs, D. R., Müller, H., Poore, R. Z., Porter, S. C., Seret, G., Shackleton, N. J., Turner, C., Tzedakis, P. C., and Winograd, I. J.: Last interglacial climates, Quaternary Res., 58, 2-13, 2002.

Labeyrie, L., Duplessy, J. C., and Blanc, P. L.: Variations in mode 
of formation and temperature of oceanic deep waters over the past 125,000 years, Nature, 327, 477-482, 1987.

Labeyrie, L., Leclaire, H., Waelbroeck, C., Cortijo, E., Duplessy, J. C., Vidal, L., Elliot, M., and Le Coat, B.: Temporal variability of the surface and deep waters of the North West Atlantic Ocean at orbital and millenial scales, Geophys. Monogr., 112, 77-98, 1999.

Labeyrie, L., Waelbroeck, C., Cortijo, E., Michel, E., and Duplessy, J. C.: Changes in deep water hydrology during the last deglaciation, C. R. Geosci., 337, 919-927, 2005.

Lambeck, K., Purcell, A., Funder, S., Kjær, K. H., Larsen, E., and Moller, P. E. R.: Constraints on the Late Saalian to early Middle Weichselian ice sheet of Eurasia from field data and rebound modelling, Boreas, 35, 539-575, doi:10.1080/03009480600781875, 2006.

Loulergue, L., Parrenin, F., Blunier, T., Barnola, J.-M., Spahni, R., Schilt, A., Raisbeck, G., and Chappellaz, J.: New constraints on the gas age-ice age difference along the EPICA ice cores, 0-50 kyr, Clim. Past, 3, 527-540, doi:10.5194/cp-3-527-2007, 2007.

Loulergue, L., Schilt, A., Spahni, R., Masson-Delmotte, V., Blunier, T., Lemieux, B., Barnola, J. M., Raynaud, D., Stocker, T. F., and Chappellaz, J.: Orbital and millennial-scale features of atmospheric $\mathrm{CH}_{4}$ over the past 800,000 years, Nature, $453,383-$ 386, 2008.

Madec, G., Delecluse, P., Imbard, M., and Levy, C.: OPA 8.1 ocean general circulation model reference manual, Institut PierreSimon Laplace (IPSL)- Note du Pôle de modélisation 11, 91 pp., 1998.

Malaizé, B. and Caley, T.: Sea surface salinity reconstruction as seen with foraminifera shells: Methods and cases studies, Eur. Phys. J. Conf. 1, 177-188, doi:10.1140/epjconf/e2009-00919-6, 2009.

MARGO Project Members: Constraints on the magnitude and patterns of ocean cooling at the Last Glacial Maximum, Nature Geoscience, 2, 127-132, doi:10.1038/ngeo411, 2009.

Marti, O., Braconnot, P., Dufresne, J. L., Bellier, J., Benshila, R., Bony, S., Brockmann, P., Cadule, P., Caubel, A., Codron, F., de Noblet, N., Denvil, S., Fairhead, L., Fichefet, T., Foujols, M. A., Friedlingstein, P., Goosse, H., Grandpeix, J. Y., Guilyardi, E., Hourdin, F., Idelkadi, A., Kageyama, M., Krinner, G., Lévy, C., Madec, G., Mignot, J., Musat, I., Swingedouw, D., and Talandier, C.: Key features of the IPSL ocean atmosphere model and its sensitivity to atmospheric resolution, Clim. Dynam., 34, 1-26, doi:10.1007/s00382-009-0640-6, 2010.

Masson-Delmotte, V., Stenni, B., Blunier, T., Cattani, O., Chappellaz, J., Cheng, H., Dreyfus, G., Edwards, R. L., Falourd, S., Govin, A., Kawamura, K., Johnsen, S. J., Jouzel, J., Landais, A., Lemieux-Dudon, B., Lourantou, A., Marshall, G., Minster, B., Mudelsee, M., Pol, K., Röthlisberger, R., Selmo, E., and Waelbroeck, C.: Abrupt change of Antarctic moisture origin at the end of Termination II, P. Natl. Acad. Sci., 107, 12091-12094, doi:10.1073/pnas.0914536107, 2010.

McManus, J. F., Oppo, D. W., and Cullen, J.: A 0.5-million-year record of millenial-scale climate variability in the North Atlantic, Science, 283, 971-975, 1999.

Meehl, G., Stocker, T. F., Collins, W. D., Friedlingstein, P., Gaye, A. T., Gregory, J. M., Kitoh, A., Knutti, R., Murphy, J. M., Noda, A., Raper, S. C. B., Watterson, I. G., Weaver, A. J., and Zhao,
Z.-C.: Global Climate Projections, in: Climate change 2007: The Physical Science Basis. Contribution of Working Group I to the Fourth Assessment Report of the Intergovernmental Panel on Climate Change, edited by: Solomon, S., Qin, D., Manning, M., Chen, Z., Marquis, M., Averyt, K. B., Tignor, M., and Miller, H. L., Cambridge University Press, Cambridge, UK and New York, NY, USA, 2007.

Meland, M. Y., Jansen, E., and Elderfield, H.: Constraints on SST estimates for the northern North Atlantic/Nordic Seas during the LGM, Quaternary Sci. Rev., 24, 835-852, doi:10.1016/j.quascirev.2004.05.011, 2005.

Miller, G. H., Brigham-Grette, J., Alley, R. B., Anderson, L., Bauch, H. A., Douglas, M. S. V., Edwards, M. E., Elias, S. A., Finney, B. P., Fitzpatrick, J. J., Funder, S. V., Herbert, T. D., Hinzman, L. D., Kaufman, D. S., MacDonald, G. M., Polyak, L., Robock, A., Serreze, M. C., Smol, J. P., Spielhagen, R., White, J. W. C., Wolfe, A. P., and Wolff, E. W.: Temperature and precipitation history of the Arctic, Quaternary Sci. Rev., 29, 1679-1715, doi:10.1016/j.quascirev.2010.03.001, 2010.

North Greenland Ice Core Project members: High-resolution climate record of Northern Hemisphere climate extending into the last interglacial period, Nature, 431, 147-151, 2004.

Oppo, D. W., Horowitz, M., and Lehman, S. J.: Marine core evidence for reduced deep water production during Termination II followed by a relatively stable substage 5e (Eemian), Paleoceanography, 12, 51-63, 1997.

Oppo, D. W., Keigwin, L. D., McManus, J. F., and Cullen, J. L.: Persistent suborbital climate variability in marine isotope stage 5 and Termination II, Paleoceanography, 16, 280-292, 2001.

Oppo, D. W., McManus, J. F., and Cullen, J.: Evolution and demise of the last interglacial warmth in the subpolar North Atlantic, Quaternary Sci. Rev., 25, 3268-3277, 2006.

Ostlund, H. G. and Grall, C.: Arctic tritium: 1973-1991, Data Report 19, University of Miami, Rosenstiel School of Marine and Atmospheric Science, 1993.

Ostlund, H. G., Craig, H., Broecker, W. S., and Spenser, D.: GEOSECS Atlantic, Pacific and Indian Ocean expeditions: Shorebased data and graphics, Nat. Sci. Found., Washington, DC, 7, 1987.

Ottens, J. J.: Planktic foraminifera as indicators of ocean environments in the northeast Atlantic, $\mathrm{PhD}$ thesis, Vrije Universiteit Amsterdam, Amsterdam, 189 pp., 1992.

Otto-Bliesner, B. L., Marshall, S. J., Overpeck, J. T., Miller, G. H., Hu, A., and members, C. L. I. P.: Simulating arctic climate warmth and icefield retreat in the Last Interglacial, Science, 311, 1751-1753, 2006.

Paillard, D., Labeyrie, L., and Yiou, P.: Macintosh program performs time-series analyses, Eos Trans. AGU, 77, 379, doi:10.1029/96EO00259, 1996.

Parrenin, F., Barnola, J.-M., Beer, J., Blunier, T., Castellano, E., Chappellaz, J., Dreyfus, G., Fischer, H., Fujita, S., Jouzel, J., Kawamura, K., Lemieux-Dudon, B., Loulergue, L., MassonDelmotte, V., Narcisi, B., Petit, J.-R., Raisbeck, G., Raynaud, D., Ruth, U., Schwander, J., Severi, M., Spahni, R., Steffensen, J. P., Svensson, A., Udisti, R., Waelbroeck, C., and Wolff, E.: The EDC3 chronology for the EPICA Dome C ice core, Clim. Past, 3, 485-497, doi:10.5194/cp-3-485-2007, 2007.

Rasmussen, T. L., Balbon, E., Thomsen, E., Labeyrie, L., and Van Weering, T. C. E.: Climate records and changes in deep outflow 
from the Norwegian Sea $<150-55 \mathrm{ka}$, Terra Nova, 11, 61-66, doi:10.1046/j.1365-3121.1999.00226.x, 1999.

Rasmussen, T. L., Oppo, D. W., Thomsen, E., and Lehman, S. J.: Deep sea records from the southeast Labrador Sea: ocean circulation changes and ice-rafting events during the last 160,000 years, Paleoceanography, 18, 1018, doi:10.1029/2001PA000736, 2003a.

Rasmussen, T. L., Thomsen, E., Kuijpers, A., and Wastegård, S.: Late warming and early cooling of the sea surface in the Nordic seas during MIS 5e (Eemian Interglacial), Quaternary Sci. Rev., 22, 809-821, 2003b.

Ridley, J. K., Huybrechts, P., Gregory, J. M., and Lowe, J. A.: Elimination of the Greenland Ice Sheet in a High $\mathrm{CO}_{2}$ Climate, J. Climate, 18, 3409-3427, doi:10.1175/jcli3482.1, 2005.

Risebrobakken, B., Dokken, T., and Jansen, E.: Extent and variability of the Meridional Atlantic Circulation in the Eastern Nordic Seas during Marine Isotope Stage 5 and its influence on the inception of the last Glacial, in: The Nordic Seas: an integrated perspective, edited by: Drange, H., Dokken, T., Furevik, T., Gerdes, R., and Berger, W. H., AGU Geophysical Monograph, 323-339, 2005

Risebrobakken, B., Balbon, E., Dokken, T., Jansen, E., Kissel, C., Labeyrie, L., Richter, T., and Senneset, L.: The penultimate deglaciation: high-resolution paleoceanographic evidence from a north-south transect along the eastern Nordic Seas, Earth Planet. Sc. Lett., 241, 505-516, 2006.

Risebrobakken, B., Dokken, T., Smedsrud, L. H., Andersson, C., Jansen, E., Moros, M., and Ivanova, E. V.: Early Holocene temperature variability in the Nordic Seas: The role of oceanic heat advection versus changes in orbital forcing, Paleoceanography, 26, PA4206, doi:10.1029/2011pa002117, 2011.

Rohling, E. J., Grant, K., Hemleben, C., Siddall, M., Hoogakker, B. A. A., Bolshaw, M., and Kucera, M.: High rates of sea-level rise during the last interglacial period, Nat. Geosci., 1, 38-42, doi:10.1038/ngeo.2007.28, 2008.

Ruddiman, W. F., Molfino, B., Esmay, A., and Pokras, E.: Evidence bearing on the mechanism of rapid deglaciation, Climatic Change, 3, 65-87, 1980.

Ruth, U., Barnola, J.-M., Beer, J., Bigler, M., Blunier, T., Castellano, E., Fischer, H., Fundel, F., Huybrechts, P., Kaufmann, P., Kipfstuhl, S., Lambrecht, A., Morganti, A., Oerter, H., Parrenin, F., Rybak, O., Severi, M., Udisti, R., Wilhelms, F., and Wolff, E.: "EDML1": a chronology for the EPICA deep ice core from Dronning Maud Land, Antarctica, over the last 150000 years, Clim. Past, 3, 475-484, doi:10.5194/cp-3-475-2007, 2007.

Saenko, O. A., Weaver, A. J., Robitaille, D. Y., and Flato, G. M.: Warming of the subpolar Atlantic triggered by freshwater discharge at the continental boundary, Geophys. Res. Lett., 34, 15604, doi:10.1029/2007GL030674, 2007.

Sarnthein, M. and Tiedemann, R.: Younger Dryas-Style Cooling Events at Glacial Terminations I-VI at ODP Site 658: Associated benthic $\delta^{13} \mathrm{C}$ anomalies constrain meltwater hypothesis, $\mathrm{Pa}-$ leoceanography, 5, 1041-1055, 1990.

Schiebel, R., Bijma, J., and Hemleben, C.: Population dynamics of the planktic foraminifer Globigerina bulloides from the eastern North Atlantic, Deep Sea Research Part I: Oceanographic Research Papers, 44, 1701-1713, doi:10.1016/S09670637(97)00036-8, 1997.

Schmidt, G. A., Bigg, G. R., and Rohling, E. J.: Global Seawater
Oxygen-18 Database - v1.21, http://data.giss.nasa.gov/o18data/, 1999.

Schmittner, A., Latif, M., and Schneider, B.: Model projections of the North Atlantic thermohaline circulation for the 21st century assessed by observations, Geophys. Res. Lett., 32, L23710, doi:10.1029/2005g1024368, 2005.

Schneider, B., Latif, M., and Schmittner, A.: Evaluation of Different Methods to Assess Model Projections of the Future Evolution of the Atlantic Meridional Overturning Circulation, J. Climate, 20, 2121-2132, doi:10.1175/JCLI4128.1, 2007.

Severinghaus, J. P. and Brook, E. J.: Abrupt Climate Change at the End of the Last Glacial Period Inferred from Trapped Air in Polar Ice, Science, 286, 930-934, 1999.

Shackleton, N. J.: The last interglacial in the marine and terrestrial records, P. Roy. Soc. Lond. B, 174, 135-154, 1969.

Shackleton, N. J.: Attainment of isotopic equilibrium between ocean water and the benthonic foraminifera genus Uvigerina: isotopic changes in the ocean during the last glacial, Colloques internationaux du CNRS, 219, 1974.

Shackleton, N. J., Hall, M. A., and Vincent, E.: Phase relationships between millenial-scale events 64,000-24,000 years ago, Paleoceanography, 15, 565-569, 2000.

Shackleton, N. J., Chapman, M. R., Sanchez-Goni, M. F., Pailler, D., and Lancelot, Y.: The classic Marine Isotope Substage 5e, Quaternary Res., 58, 14-16, 2002.

Siddall, M., Rohling, E. J., Almogi-Labin, A., Hemleben, C., Meischner, D., Schmelzer, I., and Smeed, D. A.: Sea-level fluctuations during the last glacial cycle, Nature, 423, 853-858, doi:10.1038/nature01690, 2003.

Skinner, L. C. and Shackleton, N. J.: An Atlantic lead over Pacific deep-water change across Termination I: implications for the application of the marine isotope stage stratigraphy, Quaternary Sci. Rev., 24, 571-580, 2005.

Skinner, L. C., Fallon, S., Waelbroeck, C., Michel, E., and Barker, S.: Ventilation of the Deep Southern Ocean and Deglacial $\mathrm{CO}_{2}$ Rise, Science, 328, 1147-1151, doi:10.1126/science.1183627, 2010.

Smith, D. E., Harrison, S., Firth, C. R., and Jordan, J. T.: The early Holocene sea level rise, Quaternary Sci. Rev., 30, 1846-1860, doi:10.1016/j.quascirev.2011.04.019, 2011.

Stenni, B., Buiron, D., Frezzotti, M., Albani, S., Barbante, C., Bard, E., Barnola, J. M., Baroni, M., Baumgartner, M., Bonazza, M., Capron, E., Castellano, E., Chappellaz, J., Delmonte, B., Falourd, S., Genoni, L., Iacumin, P., Jouzel, J., Kipfstuhl, S., Landais, A., Lemieux-Dudon, B., Maggi, V., Masson-Delmotte, V., Mazzola, C., Minster, B., Montagnat, M., Mulvaney, R., Narcisi, B., Oerter, H., Parrenin, F., Petit, J. R., Ritz, C., Scarchilli, C., Schilt, A., Schupbach, S., Schwander, J., Selmo, E., Severi, M., Stocker, T. F., and Udisti, R.: Expression of the bipolar seesaw in Antarctic climate records during the last deglaciation, Nat. Geosci., 4, 46-49, doi:10.1038/ngeo1026, 2011.

Stephens, C., Antonov, J. I., Boyer, T. P., Conkright, M. E., Locarnini, R. A., O'Brien, T. D., and Garcia, H. E.: World Ocean Atlas 2001, Volume 1: Temperature, in: NOAA Atlas NESDIS 49, edited by: Levitus, S., U.S. Government Printing Office, Washington, DC, 167, 2002.

Stouffer, R. J., Yin, J., Gregory, J. M., Dixon, K. W., Spelman, M. J., Hurlin, W., Weaver, A. J., Eby, M., Flato, G. M., and Hasumi, H.: Investigating the Causes of the Response of the Thermohaline 
Circulation to Past and Future Climate Changes, J. Climate, 19, 1365-1387, 2006.

Svendsen, J. I., Alexanderson, H., Astakhov, V. I., Demidov, I., Dowdeswell, J. A., Funder, S., Gataullin, V., Henriksen, M., Hjort, C., Houmark-Nielsen, M., Hubberten, H. W., Ingolfsson, O., Jakobsson, M., Kjær, K. H., Larsen, E., Lokrantz, H., Lunkka, J. P., Lysaa, A., Mangerud, J., Matiouchkov, A., Murray, A., Möller, P., Niessen, F., Nikolskaya, O., Polyak, L., Saarnisto, M., Siegert, C., Siegert, M. J., Spielhagen, R. F., and Stein, R.: Late Quaternary ice sheet history of northern Eurasia, Quaternary Sci. Rev., 23, 1229-1271, doi:10.1016/j.quascirev.2003.12.008, 2004.

Swingedouw, D., Braconnot, P., Delecluse, P., Guilyardi, E., and Marti, O.: The impact of global freshwater forcing on the thermohaline circulation: adjustment of North Atlantic convection sites in a CGCM, Clim. Dynam., 28, 291-305, 2007 a.

Swingedouw, D., Braconnot, P., Delecluse, P., Guilyardi, E., and Marti, O.: Quantifying the AMOC feedbacks during a $2 \times \mathrm{CO}_{2}$ stabilization experiment with land-ice melting, Clim. Dynam., 29, 521-534, 2007b.

Swingedouw, D., Mignot, J., Braconnot, P., Mosquet, E., Kageyama, M., and Alkama, R.: Impact of Freshwater Release in the North Atlantic under Different Climate Conditions in an OAGCM, J. Climate, 22, 6377-6403, 2009.

Thompson, W. G. and Goldstein, S. L.: A radiometric calibration of the SPECMAP timescale, Quaternary Sci. Rev., 25, 3207-3215, doi:10.1016/j.quascirev.2006.02.007, 2006.

Van Nieuwenhove, N. and Bauch, H. A.: Last interglacial (MIS 5e) surface water conditions at the Vøring Plateau (Norwegian Sea), based on dinoflagellate cysts, Polar Res., 27, 175-186, doi:10.1111/j.1751-8369.2008.00062.x, 2008.

Van Nieuwenhove, N., Bauch, H. A., Eynaud, F., Kandiano, E., Cortijo, E., and Turon, J.-L.: Evidence for delayed poleward expansion of North Atlantic surface waters during the last interglacial (MIS 5e), Quaternary Sci. Rev., 30, 934-946, doi:10.1016/j.quascirev.2011.01.013, 2011.

Waelbroeck, C., Duplessy, J. C., Michel, E., Labeyrie, L., Paillard, D., and Duprat, J.: The timing of the last deglaciation in North Atlantic climate records, Nature, 412, 724-727, 2001.
Waelbroeck, C., Labeyrie, L., Michel, E., Duplessy, J. C., McManus, J. F., Lambeck, K., Balbon, E., and Labracherie, M.: Sea-level and deep water temperature changes derived from benthic foraminifera isotopic records, Quaternary Sci. Rev., 21, 295305, 2002.

Waelbroeck, C., Levi, C., Duplessy, J. C., Labeyrie, L., Michel, E., Cortijo, E., Bassinot, F., and Guichard, F.: Distant origin of circulation changes in the Indian Ocean during the last deglaciation, Earth Planet. Sc. Lett., 243, 244-251, 2006.

Waelbroeck, C., Frank, N., Jouzel, J., Parrenin, F., MassonDelmotte, V., and Genty, D.: Transferring radiometric dating of the last interglacial sea level high stand to marine and ice core records, Earth Planet. Sc. Lett., 265, 183-194, 2008.

Waelbroeck, C., Skinner, L. C., Labeyrie, L., Duplessy, J. C., Michel, E., Vazquez Riveiros, N., Gherardi, J. M., and Dewilde, F.: The timing of deglacial circulation changes in the Atlantic, Paleoceanography, 26, PA3213, 10.1029/2010pa002007, 2011.

Wastegaard, S. and Rasmussen, T. L.: New tephra horizons from Oxygen Isotope Stage 5 in the North Atlantic: correlation potential for terrestrial, marine and ice-core archives, Quaternary Sci. Rev., 20, 1587-1593, doi:10.1016/S0277-3791(01)00055-5, 2001.

Weldeab, S., Lea, D. W., Schneider, R. R., and Andersen, N.: 155,000 Years of West African Monsoon and Ocean Thermal Evolution, Science, 316, 1303-1307, doi:10.1126/science.1140461, 2007.

Willerslev, E., Cappellini, E., Boomsma, W., Nielsen, R., Hebsgaard, M. B., Brand, T. B., Hofreiter, M., Bunce, M., Poinar, H. N., Dahl-Jensen, D., Johnsen, S., Steffensen, J. P., Bennike, O., Schwenninger, J.-L., Nathan, R., Armitage, S., de Hoog, C.-J., Alfimov, V., Christl, M., Beer, J., Muscheler, R., Barker, J., Sharp, M., Penkman, K. E. H., Haile, J., Taberlet, P., Gilbert, M. T. P., Casoli, A., Campani, E., and Collins, M. J.: Ancient Biomolecules from Deep Ice Cores Reveal a Forested Southern Greenland, Science, 317, 111-114, doi:10.1126/science.1141758, 2007. 